\title{
The Amaraughaprabodha: New Evidence on the Manuscript Transmission of an Early Work on Haṭha- and Rājayoga
}

\author{
Jason Birch ${ }^{1}$ (D)
}

Published online: 2 July 2019

(C) The Author(s) 2019

\begin{abstract}
The Amaraughaprabodha is a Sanskrit Śaiva yoga text attributed by its colophons to Gorakṣanātha. It was published by Kalyani Devi Mallik in 1954 and has been discussed in various secondary sources. Most notably, Christian Bouy (1994, pp. 18-19) identified this work as a source text for the Hathapradipika of Svātmārāma (mid- fifteenth century). This article presents new manuscript evidence for a shorter recension of the Amaraughaprabodha than the one published by Mallik. Comparing the differences between the short and long recensions reveals that the structure of the shorter one is more cohesive and closer to the original design of the work. The close relationship of the Amaraughaprabodha's short recension with an eleventh-century Vajrayāna work on yoga called the Amrtasiddhi provides unique insights into how early teachings on Hathayoga were formulated. Although the practice of the physical techniques is largely the same in both texts, the author of the Amaraughaprabodha removed or obscured Vajrayāna terminology, added Śaiva metaphysics and framed Hathayoga as subordinate to a Śaiva yoga known as Rājayoga. This article proposes that the Amaraughaprabodha's short recension is probably the earliest known work to combine Hatha- with Rājayoga, on the basis of this recension's close relationship with the Amrtasiddhi, its rudimentary nature and the likelihood that Svātmārāma used it, and not the long recension, for composing the Hathapradīpikā.
\end{abstract}

Keywords Yoga $\cdot$ South Asia $\cdot$ Indology $\cdot$ Manuscripts $\cdot$ Hatha · Raja $\cdot$ Vajrayana $\cdot$ Hinduism $\cdot$ Buddhism

Jason Birch

letusconnect@hotmail.com

1 SOAS University of London, Office 451b, Thornhaugh Street, Russell Square, London WC1H 0XG, UK 


\section{Introduction}

The Amaraughaprabodha, which literally means 'awakening a flood of nectar', is a Sanskrit yoga text that attributes its teachings to Gorakșanātha, the alleged founder of the Nātha order and a physical type of yoga called Hathayoga. This text was first published in 1954 by Kalyani Devi Mallik, whose edition is a transcription of one manuscript. The text has seventy-five verses and has been dated by Bouy (1994, pp. 18-19) and others as being prior to the mid-fifteenth century, on the basis that Svātmārāma, the author of the Hațapradīpikā, borrowed verses from it (Bouy 1994, p. 19). ${ }^{1}$ This article aims to reassess these conclusions in light of newly discovered manuscript evidence which indicates that two recensions of the Amaraughaprabodha exist; a longer one, as published by Mallik, and a shorter one that is preserved by two unpublished manuscripts. An analysis of the manuscript transmission and the differences between the recensions reveals that the shorter recension is the older of the two and was probably the one known to Svātmārāma. Its rudimentary nature and close relationship with an eleventh-century Vajrayāna work called the Amrtasiddhi make it probable that the short recension of the Amaraughaprabodha was one of the earliest works to teach a fourfold system of yoga that combined Hatha- with Rājayoga. The article concludes by discussing the significance of these findings within the broader history of yoga.

\section{Previous Attempts to Date the Text}

Bouy (1994, p. 19) examined the Amaraughaprabodha in Mallik's edition and identified twenty-two and half of its verses in the Hathapradipika ${ }^{2}$ In spite of the fact that Svātmārāma does not reveal the names of his sources, Bouy proposed that Svātmārāma borrowed the Amaraughaprabodha's verses by demonstrating that the Hathapradīpikā is an anthology (1994, pp. 80-86). If one accepts this logic behind the direction of borrowing, the Amaraughaprabodha was composed before the midfifteenth century. Bouy (1994, p. 19) also notes that the Upāsanāsārasañgraha, which he dates from the sixteenth to seventeenth century (1994, p. 91), cites the Amaraughaprabodha by name. This provides a certain, albeit more recent, terminus ad quem. ${ }^{3}$

\footnotetext{
${ }^{1}$ Mallinson (2011, pp. 771-772, 2016b, pp. 111-113) and Birch (2011, p. 528).

2 Mallinson (2014, p. 239) has estimated that the Hathapradīiki à borrowed twenty and a half verses from the Amaraughaprabodha. The discrepancy occurs because Bouy includes Amaraughaprabodha 9, which is very similar to Hathapradīpika 4.14 , and Amaraughaprabodha 38b-39a, which may have been heavily redacted to create Hathapradīpikā 3.25c-26a.

${ }^{3}$ Bouy (1994, p. 19) does not provide a reference in the Upāsanāsārasangraha to its citation of the Amaraughaprabodha. Instead, he (1994, p. 9 n. 5, 19 n. 55) says that the reference would be included in a forthcoming article. However, it seems that this article was never published. Although I have access to only chapters 3, 4 and 7 (out of 24), I can confirm that Amaraughaprabodha 38-41 is quoted with attribution (i.e., amaraughe) in the seventh chapter of the Upāsanāsārasangraha (IFP T1095, p. 48).
} 
Mallinson (2016) has identified at least five verses of the Amaraughaprabodha in the eleventh-century Amrtasiddhi. ${ }^{4}$ Furthermore, the version of the Amaraughaprabodha in Mallik's edition has borrowed a verse from the second chapter of the Amanaska (Birch 2011, p. 528), which can be dated to the eleventh or early twelfth century (Birch 2014, p. 406 n. 21), and another from the Dattātreyayogaśāstra, circa thirteenth century. ${ }^{5}$ There is also a verse cited and attributed to the Śrisamputa $a^{6}$ and a short passage attributed to the Amaraughasamsiddhi. ${ }^{7}$ These borrowings indicate that the Amaraughaprabodha in Mallik's edition is a compilation, the terminus a quo of which was the Dattātreyayogaśāstra, bearing in mind that the Śrsamputa and the Amaraughasamsiddhi are unknown works. These observations led me to propose in an earlier publication (Birch 2011, p. 528) that the Amaraughaprabodha was probably composed in the fourteenth century, because it must have appeared after the earliest Hatha- and Rājayoga texts and before the Hathapradīpikā. The discovery of new manuscript evidence requires that these conclusions be revised.

\section{Authorship}

Among the earliest modern publications that mention the Amaraughaprabodha in any detail are the first volume of Madras University's New Catalogus Catalogorum (1949) and Mallik's edition (1954). Both attribute it to Gorakṣanātha. Before these publications, the Amaraughaprabodha is absent in lists of Gorakșanātha's works by modern scholars (e.g., Briggs 1938, pp. 251-257 and Dvivedī 1950, pp. 98-100) and in studies on the Nāths (e.g., Dasgupta 1946, pp. 219-294). However, it has

\footnotetext{
4 Amaraughaprabodha 20, 32cd, 37ab, 37cd, 38, 39cd, 40ab 45, 50c, 51ab = Amrtasiddhi 16.1cd-16.2ab, $11.9 \mathrm{~cd}, 11.3 \mathrm{~cd}, 14.5 \mathrm{~cd}, 14.6,13.5 \mathrm{~cd}, 13.7 \mathrm{~cd}, 19.2,25.1 \mathrm{c}, 22.2 \mathrm{~cd}$. Other sections of the Amaraughaprabodha appear to have been inspired by the Amrtasiddhi. For example, a passage on the four types of student (Amaraughaprabodha 18-24), in particular the last called adhimätratara, is close to Amrtasiddhi $15.1,15.3,16.1 \mathrm{~cd}-17.1,18.1-5$ and a sequence of piercing knots (granthi) that causes various sounds to arise (Amaraughaprabodha 46-52) has some similarities to Amrtasiddhi 13.10-11, 20.1ab, 20.7, 22.2cd, 25.1c, 31.1ab. The connection between the Amaraughaprabodha and the Sivasamhitā is less certain, despite the fact that they share a similar verse (Amaraughaprabodha $3 \sim$ Sivasamhitā 5.12) and have some identical compounds in the passage on the four types of student (e.g., Amaraughaprabodha 19, 21, $22 \sim$ Śivasamhitā 5.14, 5.21, 5.24). The Śivasamhitā is a compilation, which borrowed a large number of verses from the Amrtasiddhi (Mallinson 2016a, pp. 127-128, n. 36). The similarities between the Amaraughaprabodha and the Śivasamhitā are largely explained by the fact that both borrow from the Amrtasiddhi. In the few instances where the Amaraughaprabodha and the Śivasamhitā have something in common that is not in the Amrtasiddhi, the direction of borrowing and the sources involved is not certain. The contradictions between the Śivasamhitä's chapters (Birch 2018, p. 107 n. 13) suggest that it has been crudely cobbled together from various sources, an unknown one of which might be responsible for Amaraughaprabodha 3 and the similar compounds in the section on the four types of student.

5 Amaraughaprabodha 71cd-72ab = Dattātreyayogaśāstra 161.

6 The Samputa is the name of a well-known Buddhist Tantra (Szántó 2016). However, the verse quoted by the Amaraughaprabodha is not found in this Buddhist work (Péter-Dániel Szántó, p.c. 27.4.2017). The verse is probably from a Śaiva text because it mentions the story of Matsyendranātha (by the name of Mīnanātha), who overheard Śiva's teachings after he is swallowed by a fish. I have not been able to find the source of this verse.
}

7 See footnote 31 . 
been included in more recent lists (e.g., Banerjea 1962, pp. 26-28, Gonda 1977, p. 222 n. 28, etc.) and studies (e.g., Bouy 1994, pp. 18-19, White 1996, p. 141, etc.).

The attribution of authorship to Gorakșanātha is supported by the final colophon of the manuscript used by Mallik, that states: "the Amaraughaprabodha, which was composed by the honourable Gorakșanātha, is complete." ${ }^{8}$ The same attribution is made in colophons of all the available manuscripts. ${ }^{9}$ The colophons were probably inspired by the mention of Gorakșanātha in three of the text's verses (2, 65 and 74). Two of these verses ( 2 and 74), at the beginning and end of the text, assert that Gorakșanattha taught the four yogas, which are the main topic of the work:

The awakening, which is proof [of itself], was taught by Gorakșanātha for those who have undertaken Laya and the other [yogas] and whose minds are quarrelsome. [...] The honourable Gorakșanātha, who always abides in samādhi, taught Laya-, Mantra- and Hathayoga solely for [the attainment of] Rājayoga. ${ }^{10}$

It is probable that the scribe who added the colophon interpreted these statements as Gorakșanātha referring to himself in the third person. However, it also possible to interpret these verses as statements made by an author within Gorakșanātha's lineage, who believed that the teachings of the Amaraughaprabodha were first revealed by Gorakșanātha. Therefore, these verses do not necessarily confirm that Gorakșanātha was the author. Nonetheless, the sectarian milieu in which the text was composed is a Śaiva siddha tradition, as evinced by the first verse, which pays homage to Ādinātha, Mīnanātha (i.e., Matsyendranātha), Caurañgīnātha and Siddhabuddha, as well as by references to Śiva elsewhere in the text. ${ }^{11}$

\section{Region}

The manuscript used by Mallik (1954, p. 34) and the six surviving manuscripts of the Amaraughaprabodha are in south-Indian scripts. It is possible that the version published by Mallik was redacted in south India, because it has nine verses in

\footnotetext{
8 Mallik (1954, p. 55) (iti śrīmadgorakṣanāthaviracitam amaraughaprabodham sampūrnam).

${ }^{9} \mathrm{G}_{1}$ (ity amaraugha[m] gorakșaviracitam sampūrṇam); $\mathrm{A}_{2}$ (ity amaraugho śrīgorakșaviracitam śatakam samāpyate); B (śrīgorakșanāthaviracitam amaraughaprabodhah sampūurnạn); $\mathrm{A}_{1}$ (iti śrīmadgorakșanāthaviracitam amaraughaprabodhah sampūrṇam); $\mathrm{G}_{2}$ (iti śrīmadgorakșanāthaviracitam amaraughaprabodhaḥ sampūrnnam); $\mathrm{T}$ (iti śrīmadgorakṣanāthaviracitam amaraughaprabodhah sampūrṇah).

${ }^{10}$ Amaraughaprabodha (Edition) 2: (layādipratipannānām kalahotsukacetasām I gorakșakena kathitaḥ prabodhah pratyayātmakah II prabodhah ] conj. : prabodha- Ed.). Amaraughaprabodha (Edition) 74 (śrīmadgorakșanāthena sadāmaraughavartinā | layamantrahațāh proktā rājayogāya kevalam). On the meaning of amaraugha as samādhi, see below. The compound sadāmaraughavartinā could also be understood as 'who always resides in the lineage (ogha) of the siddhas (amara).'

11 The beta recension of the Amaraughaprabodha has only a hemistich that pays homage to Cauranigīnātha and Buddhasiddha. Whether the salutations to Ādinātha and Matysendranātha were lost in the transmission of this recension is difficult to say. Nonetheless, Siva is the object of meditation in both the Amaraughaprabodha's Mantrayoga (25) and Layayoga (27). Also, the Rājayogin's final accomplishment is to become similar to Śiva (64). Other Śaiva elements are discussed below.
} 
common with the fifth chapter of the Varāhopanișat. ${ }^{12}$ This Upanișad is a compilation that was created in the mid-eighteenth century as part of the southIndian corpus of one hundred and eight Upanișads (Bouy 1994, p. 106). If the long version of the Amaraughaprabodha was a source for this Upanișad, ${ }^{13}$ then it would have been known in south India in the eighteenth century, which may account for why its surviving manuscripts are in south-Indian scripts. Nonetheless, there is new evidence, which I will discuss below, that suggests a shorter version of the Amaraughaprabodha was composed in south India.

\section{Manuscript Transmission}

There are six manuscripts of the Amaraughaprabodha reported in various catalogues by the Kaivalyadhama Yoga Institute's Descriptive Catalogue of Yoga Manuscripts (2005, pp. 22-25), ${ }^{14}$ and five of them have been consulted for this article. ${ }^{15}$ Also, another manuscript has been found and consulted at the Venkateśvara Oriental Institute in Tirupati. ${ }^{16}$ The six manuscripts consulted for this article are on palm-leaf and written in Grantha script. None of them have a scribal date. Four of the six preserve the version of the text in Mallik's edition. ${ }^{17}$ Unfortunately, the single manuscript upon which Mallik's edition was based has been lost by the library that used to hold it. ${ }^{18}$

\footnotetext{
${ }^{12}$ Amaraughaprabodha 38-41ab = Varāhopanișat 5.60cd-5.63 and Amaraughaprabodha 56-61ab Varähopanisat 5.1-5.6ab. There are also five and a half verses common to the Amaraughaprabodha (4751ab, 52cd-53ab) and the Saubhāgyalakșmyupanișat (2.5cd-10). However, all of these verses and more occur in the Hathapradipiki $\bar{a}$, so the Amaraughaprabodha text was probably not a source for the Saubhāgyalakș̣n̄i. Bouy (1994, p. 85) notes that Hathapradīpikā 4.5-7, 4.68-77b = Saubhāgyalakșmī $2.14-16$ and $2.4-10$.

${ }^{13}$ Bouy (1994, p. 92 [table]) notes that verses 50-75 of the fifth chapter of the Varähopanișat were borrowed from the Upāsanāsārasangraha, which cites the Amaraughaprabodha elsewhere (see footnote 3). Therefore, it is unlikely that Varähopanișat 5.60cd-5.63 was borrowed from the Amaraughaprabodha, but Varāhopanișat 5.1-5.6ab ( Amaraughaprabodha 56-61ab) may well have been.

${ }^{14}$ This catalogue (2005, pp. 24-25) mentions a seventh manuscript of the Amaraughaprabodha, which is said to be at the Government Oriental Manuscripts Library in Chennai. It reports the manuscript number as D-4349. However, the catalogue of Rangācarya and Bahudur (1910, p. 3229) for this library indicates that D-4349 is a manuscript of the Pātañjalayogasūtram. Therefore, the Kaivalyadhama catalogue appears to be mistaken here.

15 Two of these are held at the Adyar Research Library (ms. Nos. 70528 and 75278), one at the M.S. University of Baroda's Oriental Institute Library (ms. No. 7970c) and two at the Government Oriental Manuscripts Library, Chennai (ms. No. D-4340 and R2831). Four of these are reported in the NCC (vol. 1 1949, p. 254); 7970c, 4339, 4340 and 2831(o). The sixth manuscript reported in Kaivalyadhama's catalogue is the one used by Mallik, which is no longer available to researchers (see footnotes 18 and 19).

16 The details of the manuscript are; serial number 412 and stock number 179(a) in Sri Venkatesvara University and Sastri: 1956. I would like to thank Dr. S. V. B. K. V. Gupta for obtaining a copy of this manuscript for me.

${ }^{17}$ Mss. Nos. 75278, D-4340, 7970c and 179(a). In this article, these are represented as $A_{1}, G_{2}, B$ and $T$ respectively.

${ }^{18}$ Mallik (1954, p. 34) gives the manuscript number as D-4339. She mentions that it has nine folios 9 and is held at 'Madras'. This information corresponds to the Descriptive Catalogue of the Government Oriental Manuscripts Library (Rañgācārya and Bahadur 1910, pp. 3220-3221).
} 


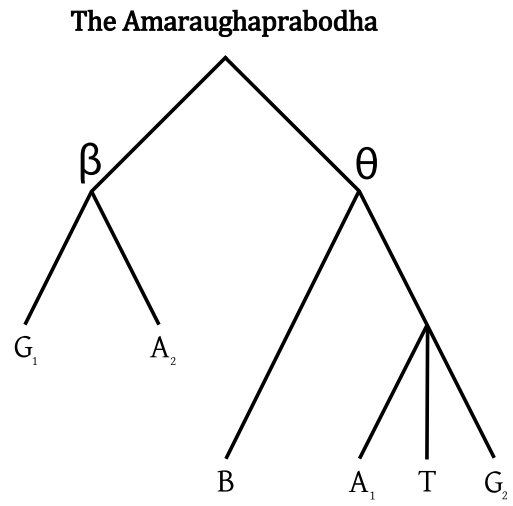

Fig. 1 A Hypothetical Stemma of the Amaraughaprabodha

This manuscript has not been available to researchers since at least $2004 .{ }^{19}$ Although Mallik places several of her conjectures in round brackets, there is evidence to suggest that her transcription has tacit emendations and inaccuracies. ${ }^{20}$

Two of the six manuscripts of the Amaraughaprabodha preserve a recension that is significantly shorter than Mallik's edition. ${ }^{21}$ This recension has forty-six verses. Both manuscripts of the shorter recension are complete and do not contain any indication of lacunae.

The stemma of the manuscript transmission bifurcates into the four manuscripts of the long recension, which I shall call the theta hyparchetype, and the two of the short recension, the beta hyparchetype, as shown in Fig. 1. The manuscripts of each group are fairly close to one another, ${ }^{22}$ although none can be dismissed as an apograph of another.

In this article, I shall argue that the beta hyparchetype predates the fifteenth century, whereas theta was possibly created sometime between the sixteenth and eighteenth centuries. If one includes Mallik's edition, there are seven available witnesses that can be used to create critical editions of both theta and beta. The

\footnotetext{
19 I first requested the manuscript in 2004 and was told that the bundle to which it belonged could not be found. I have since requested it in 2010 and 2016, but to no avail.

20 The descriptive catalogue of the Government Oriental Manuscripts Library (Rañgācārya and Bahadur 1910, pp. 3220-3221) transcribed the first four and last five verses of manuscript D-4339. When one compares this transcription to Mallik's edition, there are two instances where the catalogue has suggested a correction in brackets, which has been adopted by Mallik (3b catalogue tritzya(kah), Mallik trtīyakah and 4a catalogue laya $(h)$, Mallik layah). Therefore, one wonders how many tacit emendations Mallik may have made. Without the manuscript at hand, it is not possible to determine whether the catalogue's transcription is more accurate than Mallik's. Nonetheless, the following discrepancies can be noted: several poor readings in the catalogue's transcription may have been tacitly emended by Mallik (e.g., 71c catalogue rājayogam padạ̣, Mallik rājayogapadaṃ; 72d catalogue kleśāpaho, Mallik kleśāpahā). Also, Mallik may have introduced the following errors: 2d catalogue prabodhah pratyayātmakah, Mallik prabodhapratyayātmakah; 4a catalogue pradișțo, Mallik pradiștah; 4c catalogue mantrayogo, Mallik mantrayogah; $72 \mathrm{c}$ catalogue bhogāspadam, Mallik bhogāspadam; 73c catalogue proktā, Mallik proktāh.

21 Mss. Nos. R2831 and 70528, represented as $\mathrm{G}_{1}$ and $\mathrm{A}_{2}$ respectively, in this article.

22 As figure 1 depicts, the manuscripts that preserve the long recension bifurcate again because mss. 75278,179 (a) and D-4340 have more identical readings in common with one another than they do with $7970 \mathrm{c}$, which has some distinct readings of beta.
} 
Table 1 Summary of the content of theta and beta recensions

\begin{tabular}{llc}
\hline Content & Theta & Beta \\
\hline Introduction $^{\text {a }}$ & $1-17$ & $1-14$ \\
Four types of student & $18-24$ & - \\
Mantrayoga & $25-26$ & $15-16$ \\
Layayoga & $27-28$ & $17-18$ \\
Hațhayoga & $29-52$ & $19-41$ \\
Rājayoga & $53-55$ & $42-44$ \\
Miscellaneous topics & $56-73$ & - \\
Conclusion & $74-75$ & $45-46$ \\
\hline
\end{tabular}

\footnotetext{
${ }^{a}$ The manuscripts provide headings for the sections on Mantra-, Laya-, Hatha- and Rājayoga. However, the sections called 'introduction', 'the four types of student', 'miscellaneous topics' and 'conclusion' are my own designations
}

reconstruction of the relatively large section on Hathayoga can be further improved by using the Amrtasiddhi, the Sivasamhitā, and the Hațapradīpikā. Also, the fifth chapter of the Varāhopanișat is helpful for editing some of the additional verses of theta.

\section{Differences between the Recensions}

Both recensions have a similar structure, except for two significant differences. The structure (with these two differences in bold) has been summarised in Table 1.

Notwithstanding significant variant readings, the sections on Mantra-, Laya-, Hatha- and Rajjayoga are largely the same. The most obvious differences between the two archetypes is, firstly, theta's ten additional verses on the four types of student and, secondly, its eighteen verses following Rājayoga, which I have called 'miscellaneous topics' for the sake of this discussion. Comparing these and other differences in theta and beta reveals that the structure of beta is more cohesive and closer to the original design of the work.

The first four verses of both theta and beta introduce the four yogas, which are the main topic of the text. In beta, this opening passage is followed by rhetorical verses on the efficacy of Rājayoga (5-9), the importance of the guru, semen (bindu) and resonance $(n \bar{a} d a)(10-12)$ and the union of Śiva and Śakti (13). The last verse of this section introduces the teachings on the four yogas by asking how they are taught (14). None of verses $1-14$ has yet been traced to an earlier source. ${ }^{23}$ In contrast to this, two or three additional verses in the introductory section of theta can be traced or identified as coming from an earlier work. One verse derives from the second

\footnotetext{
23 The possible exception is verse 2 ( S Sivasamhitā 5.12). However, this verse is almost generic among texts that teach the fourfold system of yoga and may have found its way into the Sivasamhitā via another text. In its current form, it is unlikely that the Sivasamhitā predates the beta recension of the Amaraughaprabodha (see footnote 4).
} 
Table 2 Question on the four yogas in beta

\begin{tabular}{ll}
\hline Verses & Content of Beta \\
\hline $14 \mathrm{~cd}$ & $\begin{array}{l}\text { layādibhih samāyuktaś caturdhodìryate katham }{ }^{\mathrm{a}} \text { । } \\
\end{array}$ \\
& How is the fourfold [yoga,] which is endowed with Layayoga and the others, taught? \\
$15-16$ & Mantrayoga \\
$17-18$ & Layayoga \\
$19-41$ & Hațhayoga \\
$42-44$ & Rājayoga \\
\hline
\end{tabular}

a I would like to thank Dominic Goodall for proposing a slight emendation in this hemistich (i.e., caturdhodìryate for caturthodīryate). Three manuscripts read caturthodīryate (i.e., $\mathrm{A}_{2}, \mathrm{G}_{1}, \mathrm{G}_{2}$ ) and the other three caturthodīyyate $\left(\mathrm{B}, \mathrm{A}_{1}, \mathrm{~T}\right)$, in which the double yakāra indicates that udīryate was probably intended. The edition appears to have tacitly emended this reading to diyate for the reason stated below

chapter of the Amanaska and another is quoted with attribution to an unknown work called the Śrisamputa. ${ }^{24}$ Therefore, the redactors of theta increased the size of the Amaraughaprabodha's introduction by adding at least two verses from other texts. Furthermore, theta's seven verses on the 'four types of student' appear to have been inspired by the Amrtasiddhi and possibly the Sivasamhitā, ${ }^{25}$ and its additional section on 'miscellaneous topics' contains a verse which can be traced to the Dattātreyayogaśāstra. ${ }^{26}$

The tracing of two verses to the Amanaska and the Dattatreyāyogaśāstra and the references in theta to the Śrisamputa and the Amaraughasamsiddhi elicit the hypothesis that the redactors of theta simply added verses to beta. The strongest evidence in support of this hypothesis is that some of the additional verses distort the structure of the text. There are two significant instances of this. Firstly, the introduction of beta ends with the question of how the four yogas are taught. This is immediately followed by the teachings on Mantra-, Laya-, Hatha- and Rājayoga, which has a logical structure, as can be seen in Table 2 .

Although the above question appears to have been emended in the edition of the Amaraughaprabodha (see Table 3), the manuscript readings suggest that the same question was posed in theta, which is then followed by a passage on the four types of student. Had the redactors of theta been more careful, they might have rewritten the initial question to ask about the types of student to whom each yoga should be taught, but this does not appear to have been done. As shown in Table 3, it is apparent that the section on the four types of student (in bold) was inserted between the question on the four yogas (17cd) and the explanation of each of them (25-55).

Secondly, much of the content of theta's additional passage on 'miscellaneous topics' (56-73) is extraneous to the main topic of the Amaraughaprabodha, which is the four yogas. This passage can be seen as consisting of three topics. The first (5661) concerns the five elements (pañcabhüta). The final statement is that their loss

\footnotetext{
${ }^{24}$ See footnote 4 .

25 See footnote 4 .

26 See footnote 4 .
} 
Table 3 Question on the four yogas in theta and the edition

\begin{tabular}{ll}
\hline Verses & Content of Theta and the Edition \\
\hline $17 \mathrm{~cd}$ & layādibhih samāyuktaś caturthodīryate katham I (theta $\left.{ }^{\mathrm{a}}\right)$ \\
& layādibhih samāyuktaś caturdhā dīyate katham I (edition ${ }^{\mathrm{b}}$ ) \\
& How is the fourfold [yoga,] endowed with Layayoga and the others, imparted? \\
& The four types of student \\
$18-24$ & Mantrayoga \\
$25-26$ & Layayoga \\
$27-28$ & Hațhayoga \\
$29-52$ & Rājayoga \\
$53-55$ &
\end{tabular}

${ }^{a}$ This is the reading of $\mathrm{G}_{2}$. The other witnesses of theta have caturthodiyyate $\left(\mathrm{B}, \mathrm{A}_{1}, \mathrm{~T}\right)$

${ }^{\mathrm{b}}$ In the edition of the Amaraughaprabodha, the question has been tacitly emended to reflect the use of the word dìyate in verse 24 on the type of students to whom each yoga is taught (mrdave dìyate mantro madhyāya laya ucyate I adhimātre hațhạ dadyād amaraugham mahattare)

leads to death and their retention (dhärana) to life. ${ }^{27}$ The motivation for adding these verses might have been to elaborate on the notion of immortality, which is introduced early in the text and mentioned as a result of Mantra- and Hathayoga. ${ }^{28}$ However, this section does not indicate how the practice of any one of the four yogas might retain the five elements and the main section on the four yogas does not mention the five elements.

The second miscellaneous topic is on how the yogin can manipulate the sun and moon in the body. After completing an unspecified practice eight times for three hours, the yogin swallows his breaths and thereby replenishes his moon and controls both his sun and semen $\left(\right.$ bindu). Bliss and the attainment of Śivahood follow. ${ }^{29}$ The

\footnotetext{
27 Amaraughaprabodha (theta) 61 ab (ittham bhūtakșayān mrtyur jīvitam bhütadhārañāt).

28 The introduction of theta has a verse that asks why one who knows the essence of semen (bindu) and the internal resonance ( $n \bar{a} d a$ ) would fear death, among other things. Amaraughaprabodha (theta) 15: "He who knows the essence of both because of the teachings of a true guru, where is the fear of bodily affliction, old age, disease, sin or death [for him]?" (yo jānāty anayoh sāram sadguror upadeśatah I kāyakleśajarāvyādhipāpamrtyubhayam kutah). By repeating om and meditating on Śiva in the heart, death is destroyed: Amaraughaprabodha (theta) 26ab: "By repeating [this] mantra one hundred thousand times, [the yogin] destroys death, which is very frightening [...]" (ekalakșajapān mrtyum nāśayed atidārunam I [...]). The practice of mahāmudrā, a technique of Hațayoga, consumes death: Amaraughaprabodha (theta) 32ab: "Great diseases and great afflictions, such as death, are consumed" (mahārogā mahākleśā jīryante maranādayah). Mahābandha, another technique of Hathayoga, also destroys death: Amaraughaprabodha 33cd: "This mahābandha is said to be a destroyer of old age and death" (kathyate sau mahābandho jarāmarananāśakah). There are three other similar examples in the section on Haṭhayoga (41, 42 and 51).

29 Amaraughaprabodha (theta) 62-64: "From having performed the practice eight times in a watch (i.e., three hours), the [yogin] swallows all his breaths. His moon remains endowed with sixteen digits, because it has been filled [by this practice]. When the mind is motionless and steady, the breath goes into the central channel. The sun reaches its zenith and semen becomes controlled. The yogin is filled with bliss and becomes like a Śiva. Then, all the supreme powers are seen [in him] after ten months" (yāmāștakakṛtābhyāsāt sarvāñ śvāsān grasaty asau I sa șoḍáakalopetaḥ śaśi tiṣthati pūrakāt \|62\| nistarange sthire citte vāyur bhavati madhyagaḥ I ravir ūrdhvapadam yāti bindur āyāti vaśyatām \|63\| ānandapūrito yogī jāyate śivasannibhah । tadaiśvaryagunāḥ sarve dŕśyante daśamāsataḥ \|64\|
} 
motivation for adding these verses might have been to support the following comment in the section on Hathayoga, "One should know the connection between

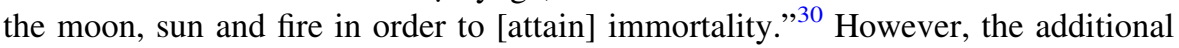
passage introduces new terminology for the sun and moon (i.e., śaśi, ravi and sodaśakalā). It may be an attempt to summarise a yoga similar to that of the Amrtasiddhi, in which case the practice done eight times for three hours would be the three mudrās of that text and the Amaraughaprabodha ${ }^{31}$. Furthermore, it is followed by a verse that suggests that the preceding verses were borrowed from a text called the Amaraughasamsiddhi, which is also attributed to Gorakșanatha.

Thus, in the Amaraughasamsiddhi, the awakening that is brought about by adeptness in the methods of Layayoga and so forth and is proof [of its own efficacy], has been revealed by Gorakșanātha. ${ }^{32}$

Therefore, it is quite likely that this passage was borrowed from another text, which was probably on the same four yogas (i.e., Mantra, Laya, Hața and Rājayoga/ amaraugha) taught by Gorakșanātha, but contained different terminology to the short version of the Amaraughaprabodha.

The third miscellaneous topic is mainly on Rājayoga and liberation-in-life (jivanmukti). The content of this passage is relevant to the central concern of the text, which is the four yogas that result in liberation. Nonetheless, it begins with a verse which was most probably taken from a Buddhist text. This verse mentions the signs of success that arise from practice, and it closely parallels a verse from the Sekoddeśa. ${ }^{33}$ This indicates that the redactors of theta had access to Buddhist material or were using texts on the four yogas that had content borrowed from Buddhist works.

A subsequent verse in this section introduces a view of liberation-in-life which goes beyond that implied by beta. Whereas beta ends with the yogin's attainment of samādhi and his becoming a second Siva, additional verses in theta, including one from the Dattātreyayogaśästra, state that the yogin emerges from samādhi to live in the world however he so wishes: ${ }^{34}$

After [liberation-in-life has been achieved], no one at all lives and no one will die. Having obtained the state of Rājayoga, which subjugates all beings, [the yogin] can do anything or nothing, behaving as he pleases. The king of yogis

\section{Footnote 29 continued}

bindur āyāti ] conj. Shaman Hatley : bindunāyāti $\mathrm{A}_{1}, \mathrm{~B}, \mathrm{G}_{2}$, T. tadaiśvaryaguṇāh ] conj. Shaman Hatley and Somadeva Vasudeva : tadeśvaragunāh $\mathrm{A}_{1}, \mathrm{~B}, \mathrm{G}_{2}, \mathrm{~T}$ ).

30 Amaraughaprabodha (theta) 41ab (somasūryāgnisambandham jānīyād amṛtāya vai).

31 I wish to thank James Mallinson for suggesting this to me.

32 Amaraughaprabodha (theta) 65 (ity amaraughasamsiddhau gorakṣeṇa prakāsitah । layādyupāyakauśalyaprabodhah pratyayātmakah \| 65a -saṃsiddhau ] $\mathrm{A}_{1}, \mathrm{G}_{2}, \mathrm{~T}, \mathrm{Ed}$ : -samsiddho $\mathrm{B}$. 65c - prabodhah ] conj. Goodall : - prabodha- B, $\left.\mathrm{A}_{1}, \mathrm{G}_{2}, \mathrm{~T}, \mathrm{Ed}\right)$.

33 Amaraughaprabodha (theta) 67 (dhūmo marīcikhadyotadīpajvālendubhāskarāh । tamah kalā mahābimbaṇ viśvabimbạ̣ prakāśate II 67a dhūmo ] $\mathrm{T}$ : rumo $\mathrm{B}, \mathrm{A}_{1}, \mathrm{G}_{2}$, Ed. 67c tamah ] diagnostic conj. : am̄̄ B, $\left.\mathrm{A}_{1}, \mathrm{G}_{2}, \mathrm{~T}, \mathrm{Ed}\right)$. Cf. Sekoddeśa 26 (dhūmamarīcikhadyotadīpajvālendubhāskaraih I tamah kalā mahābindurviśvabimbạ̣ prabhāsvaram).

34 I have discussed these differences in conceptions of jivvanmukti in Birch (2019) (forthcoming). 
[may be] someone who [lives] naked in caves, wears divine clothes or sometimes [just] a loin cloth. He may be one who has great sex with divine women somewhere or elsewhere he may be a celibate. Sometimes he is intent on eating alms and at other times he obtains the state of wealth. His behaviour is always free and he allays all suffering. ${ }^{35}$

There is no apparent reason as to why the passage on five elements is followed by another on the sun and moon and then further verses on Rājayoga and liberation. The infelicitous position of these additional verses suggests that this section of theta was hastily redacted and inserted into the Amaraughaprabodha. The redactor appears to have used at least one unknown work on the topic of amaraugha (i.e., the Amaraughasamsiddhi), as well as Buddhist material and an early yoga text on the same four yogas (i.e., the Dattātreyayogaśāstra).

There is one other addition in theta that provides some insight into how it was redacted. In the section on Hathayoga, a verse has been added to the beginning of the description of mahāvedha. ${ }^{36}$ The first hemistich of this verse occurs in the Amrtasiddhi (11.3cd), but the context is different. In the Amrtasiddhi, this hemistich describes the yogin's posture in mahämudrā, whereas in theta it is appended to a passage on mahāvedha. ${ }^{37}$ The second hemistich of the additional verse was taken from a different chapter of the Amrtasiddhi $(14.5 \mathrm{~cd})$. The inclusion of both hemistiches reveals that the redactor of theta used the Amrtasiddhi to augment and emend the original Amaraughaprabodha. Nonetheless, despite having access to the source text, it appears that this redactor did not understand the practice of mahāvedha in the Amrtasiddhi, nor any Hathayoga text for that matter, because this $m u d r a \overline{~ i s ~ n o t ~ s u p p o s e d ~ t o ~ b e ~ d o n e ~ w i t h ~ b o t h ~ h a n d s ~ h o l d i n g ~ o n e ~ e x t e n d e d ~ l e g . ~}{ }^{38}$

One might ask whether the opposite hypothesis to the one I have just discussed is at all likely. In other words, could beta be a more recent, truncated version of theta or, more to the point, can beta be seen as a deliberate attempt to rectify the problems of theta? Perhaps, a redactor omitted the passages in theta that are unrelated to the four yogas and removed theta's worst imperfections. It is true that the absence of

\footnotetext{
35 Amaraughaprabodha (theta) 71-73 (na jīvati tatah ko 'pi na ca ko 'pi marișyati I rājayogapadam prāpya sarvasattvavaśan்karam $\|71\|$ sarvam kuryān na kuryād vā yathāruci viceștitam $\|72\|$ nagnah ko 'pi guhāsu divyavasanah kaup̄̄navāsāh kva cid divyastrīsuratānvito 'pi kuha cit sa brahmacārī kva cit I bhikșāhāraratah kva cit kva cid api prāpnoti bhogāspadạ̣ sarvatrāpratibaddhavṛttir akhilakleśāpahā yogirāt II 71b marișyati ] B, T, Ed : marișyatmi A1 : ++++ G2. rājayogapadam ] B, G2 : rājayogam padam A1, T, Ed. 72a sarvam ] sarva $\mathrm{B} .72 \mathrm{~b}$ kūryān na ] omitted B. 73a vāsāh ] B, $\mathrm{A}_{1}, \mathrm{~T}:$ vāsā $\mathrm{G}_{2} .73 \mathrm{~b}$ 'pi ] omitted $\mathrm{T}$ (unmetr.) 73d pratibaddha- ] $\mathrm{A}_{1}, \mathrm{G}_{2}$, Ed: pratibandha- B, T). Cf. Dattātreyayogaśāstra 161 (rājayogavaram prāpya sarvasattvavaśaṃkaram I sarvam kuryān na vā kuryād yathāruci viceștitam).

36 Amaraughaprabodha (theta) 37: (savyam prasāritam pādam karābhyām dhārayed dṛ̣̂ham । āndolanam tataḥ kuryāe charīrasya trimārgataḥ ॥ 37cd kuryāc charīrasya ] B : kūryāch śarīrasya $\mathrm{A}_{1}$, $\mathrm{G}_{2}$ : kūryāt śarīrasya $\left.\mathrm{T}\right)$. Amaraughaprabodha $($ theta) $37 \mathrm{ab}=$ Amrtasiddhi $11.3 \mathrm{~cd}=$ Hațapradīpika 3.10cd $\sim$ Śivasaṃhitā 4.27ab (descriptions of mahāmudrā). Amaraughaprabodha (theta) 37cd = Amrtasiddhi $14.5 \mathrm{~cd}$.

37 Amrtasiddhi 11.3cd: "The [yogin] should hold firmly with both hands the left leg which has been extended" (savyam prasāritam pādam karābhyām dhārayed dṛ̣ham). Cf. Amaraughaprabodha (theta) $37 \mathrm{ab}$ (see footnote 35).

38 As far as I'm aware, the theta recension of the Amaraughaprabodha (37ab) is unique in instructing that one leg should be extended for the practice of mahāvedha.
} 
some of theta's passages, such as the four types of student and the five elements, makes the structure of beta more coherent. However, if creating a better structure were the purpose behind beta, one would have to explain why theta's final verses on Rājayoga and liberation-in-life were deliberately removed, because they are relevant to the central topic of the four yogas. Furthermore, had the redactor of beta simply removed problematic verses of theta, it is unclear why this redactor also removed verses that are coherent but were borrowed from other texts, such as the Amanaska and the Dattātreyayogaśāstra. As we shall see below, the hypothesis that beta followed theta becomes even less likely when one attempts to date and understand the content of both recensions within the broader history of works that teach the same four yogas.

\section{Dating the Recensions}

The terminus a quo of the beta recension of the Amaraughaprabodha is the Amrtasiddhi and not the Dattātreyayogaśāstra. The Amrtasiddhi was composed before $1160 \mathrm{CE}$, which is the date of a colophon in the oldest available manuscript. ${ }^{39}$ This Vajrayāna work does not teach a system of yoga called Hatha- or Rājayoga, but it was nonetheless a source text for three important Hațayogic mudrās, namely mahāmudrā, mahābandha and mahāvedha, and four distinct stages of yoga (ärambha, ghața, paricaya and nispatti). The close relationship between the Amrtasiddhi and the beta recension of the Amaraughaprabodha and the fact that this recension does not borrow from another work on Hatha- and Rājayoga make it probable that the Amaraughaprabodha was one of the earliest works to formulate a fourfold system which included Hatha- and Rājayoga.

The terminus ad quem of the beta recension remains the Hathapradīpikā, as Bouy determined. However, it is probable that Svātmārāma knew only the beta recension, because none of the additional twenty-nine verses of theta can be found in the Hathapradīpikā. These include theta's additional verses on Rājayoga, which would have been relevant to the fourth chapter of the Hathapradipika . Although the following evidence is not conclusive, there are two differences between theta and beta that are significant enough to suggest that Svātmārāma borrowed from beta. Firstly, in one place, the order of the hemistiches diverges in beta and theta, and the order in beta is the same as that in the Hathapradipik $\bar{a} .{ }^{40}$ The second difference

\footnotetext{
${ }^{39}$ For information on the dating of this manuscript, see Schaeffer (2002, p. 517), Mallinson (2016a, pp. 2-3) and Mallinson and Szántó (forthcoming).

40 Amaraughaprabodha (beta) 31-32 = theta 42ab, 43ab, 42cd, 43cd = Hathapradīpika 3.30-31.
} 
concerns the additional verse on mahāvedha in theta. The Hathapradīpikāas description of the yogin's posture for mahāvedha is more, but not entirely, consistent with beta than theta. ${ }^{41}$

A comparison of the variant readings of theta and beta with the critical edition of the Hathapradipika indicates that beta has twice the number of significant variant readings in common the Hathapradipika than theta (see "Appendix"). Although this result is worth noting, it is not in itself conclusive evidence for assessing whether theta or beta was the source of the Hathapradipika , because the comparison is based on a small sample of verses and on a critical edition of the Hathapradipika that is not dependable nor comprehensive in the manuscripts it reports. ${ }^{42}$ Nonetheless, this comparison raises an interesting question: if theta postdates the Hathapradipik $\bar{a}$, why would it have readings in common with the Hathapradipika that are not found in beta? If it is indeed true that theta was redacted sometime after the Hathapradīpika , then its transmission must have been contaminated by manuscripts of the Hathapradīpika. This contamination seems plausible because its redactor was, after all, inserting material from other yoga texts.

The terminus ad quem of the Amaraughaprabodha's theta recension may be the eighteenth-century Varāhopanișat. It remains somewhat uncertain as to whether theta was a source for this Upanișad, because the available manuscripts of the Upāsanāsārasangraha are incomplete and, as Bouy (1994, p. 19) noted, the fifth chapter of the Varāhopanișat contains a large passage that was borrowed from the Upāsanāsārasangraha. ${ }^{43}$ The only other evidence, as far as I am aware, for the theta's terminus ad quem is the four palm leaf manuscripts that preserve it, none of which is dated nor likely to be older than the eighteenth century.

\footnotetext{
${ }^{41}$ Hathapradīpikā 3.26-27ab (mahābandhasthito yogì krtvā pūrakam ekadhīh I vāyūnām gatim āvṛtya nibhrtam kaṇthamudrayā II samahastayugo bhūmau sphicau sanādayec chanaih). Cf. Amaraughaprabodha (beta) 27-28ab (punar āsphālayed kațām susthirạ̣ kanțhamudrayā I vāyūnām gatim ārudhya krtvā pūrakakumbhakau ॥ samahastayugo bhūmau samapādayugas tathā) and Amaraughaprabodha (theta) 37 (see footnote 35). The posture for mahāvedha in the Amaraughaprabodha is similar to that described in the Amrtasiddhi (i.e., a squatting type position in which the legs and arms are symmetrical), whereas in the Hathapradīpikā the posture is a cross-legged position, as stipulated for mahäbandha (see Hathapradīpikā 3.19).

42 The only critical edition of the Hathapradīpikā is that by Swami Digambaraji and Pt. Raghunatha Shastri Kokaje in 1970 at the Kaivalyadhama, S.M.Y.M. Samiti. Most of the manuscripts which they used for this edition are from libraries in the state of Mahārāsțra, so it is unlikely that regional differences in the transmission of this pan-Indic work are represented by their edition. More importantly, the editors appear to have been unaware of the significant number of parallel verses in early yoga texts such as the Dattātreyayogaśāstra, the Amrtasiddhi, the Amanaska, etc. Also, the critical apparatus is negative and it appears to include only the most important variants; the oldest manuscript has not been consulted (Bouy 1994, p. 84 n. 357) and the section on vajroli has been distorted by the editors' belief that Hathayoga did not teach transgressive practices; e.g., the verse on amaroli which describes it as drinking urine and emanating from a Kāpālika tradition has been relegated to a footnote (Hațapradīpikā 1998: 112 n. 170), in spite of the fact that most of the manuscripts have it.

43 In footnote 3, I mentioned that the Upāsanāsārasañgraha cites with attribution Amaraughaprabodha 38-41. These verse numbers are based on Mallik's edition of the Amaraughaprabodha (i.e., the theta recension), which Bouy used. However, it is very likely that the Upāsanāsārasaingraha borrowed from the beta recension of the Amaraughaprabodha (27-30) and not theta, because an additional verse on mahāmudrā in theta (for details, see footnote 35) is omitted from the Upāsanāsārasaingraha's passage on this $m u d r \bar{a}$, which it attributes to the Amaraughaprabodha.
} 
Table 4 Parallel verses in the Amaraughaprabodha and the Amrtasiddhi

\begin{tabular}{llll}
\hline Amaraughaprabodha's Hațhayoga & Verses & $\begin{array}{l}\text { Corresponding verses } \\
\text { of the Amrtasiddhi }\end{array}$ & $\begin{array}{l}\text { Chapter topic of the } \\
\text { Amrtasiddhi }\end{array}$ \\
\hline Mahāmudrā & $19-23 \mathrm{ab}$ & $\sim 11.3$ & Mahāmudrā \\
Mahābandha & $23 \mathrm{~cd}-26$ & $=12.9 \mathrm{~cd}$ & Mahābandha \\
Mahāvedha & $27-30$ & $=14.6,13.5 \mathrm{~cd}$ & Mahāvedha and Practice \\
Practice and Results of the Mudrās & $31-33$ & $=13.7 \mathrm{~cd}$ & Mahāvedha \\
The Four Stages & 34 & $\sim 19.2$ & The Four Stages ${ }^{\mathrm{a}}$ \\
Ārambha (piercing brahmāgranthi) & $35-37$ & $\sim 13.10-11$ & Mahāvedha \\
Ghața (piercing viṣnugranthi) & $38-39 \mathrm{ab}$ & $\sim 20.1 \mathrm{ab}$ & Ghața Stage \\
Paricaya (natural bliss arises) & $39 \mathrm{~cd}-40$ & $\sim 20.7$ & Ghața Stage \\
Nișpatti (piercing rudraganthi) & $41-43$ & $\sim 22.2 \mathrm{~cd}, 25.1 \mathrm{c}, 31.1 \mathrm{ab}$ & Great Bliss, Mastery of \\
& & & Breath and Mahāmudrā \\
\hline
\end{tabular}

\footnotetext{
a The name of this chapter is 'the completion of the first stage' (prathamāvasthāniṣpatti). However, I have referred to its contents as 'the four stages' because its opening discussion reflects this
}

\section{The Significance of the Amaraughaprabodha's Beta Recension in the History of Yoga}

The close relationship of the beta recension of the Amaraughaprabodha with the Amrtasiddhi, or perhaps a rudimentary version of the Amrtasiddhi, provides unique insights into how early teachings on Hathayoga were formulated. Unlike early Hatha- and Rājayoga texts, the Amrtasiddhi contains extensive, detailed passages on the theory behind the practice, which reveal that its teachings were intended for esoteric Buddhists who had rejected deity yoga. ${ }^{44}$ As I shall discuss below, the redactor of the Amaraughaprabodha borrowed and modified only select portions of the Amrtasiddhi, omitting much of the theory in the process, and introduced new ideas to formulate a system of Hathayoga that would have appealed to Śaivas. Also, the sparing application of doctrine and metaphysics in the Amaraughaprabodha probably made its yoga more accessible to people of other religions.

The section on Hathayoga in the Amaraughaprabodha is a terse account of the practice of the three mudrās and the four stages of yoga that are similar to those in the Amrtasiddhi. As seen in Table 4, the content of the Amaraughaprabodha largely derives from nine of the Amrtasiddhi's thirty-six chapters.

In spite of this shared content, a significant difference between the Amaraughaprabodha and the Amrtasiddhi is that the latter has extensive chapters on the theory and metaphysics underlying the practice of the mudrās and the stages of yoga that follow it. These additional chapters are in bold in Table 5. Most of the content of these chapters is not mentioned at all in the Amaraughaprabodha.

\footnotetext{
44 On the Amṛtasiddhi's sectarian affiliation and polemics against svādhișthānayoga, see Mallinson (2016a) and Szántó (2016).
} 
Table 5 Chapters of the Amrtasiddhi without parallel verses in the Amaraughaprabodha (indicated in bold)

Chapter headings of the Amrtasiddhi

\begin{tabular}{lll}
\hline 1. śarīra & 12. mahābandha & 26. samādhi \\
2. madhyamāyāḥ sāmānya & 13. mahāvedha & 27. siddhacitta \\
3. candra & 14. abhyāsa & 28. kāyasiddhi \\
4. sūrya & 15-18 [four types of student $\left.{ }^{a}\right]$ & 29. tṛtīyāvasthā \\
5. vahni & 19. prathamāvasthā & 30. jīvanmuktilakṣaṇa \\
6. sāmānyavāyu & 20. ghațāvasthā & 31. mahāmudrā \\
7. bindudhāraṇa & 21. ānandakāla & 32. asiddhakāyalakṣaṇa \\
8. citta & 22. sahajānanda & 33. asiddhavāyulaḳsaṇa \\
9. prakṛti & 23. prakṛtiguṇa & 34. mahābhūtapariṇāma \\
10. guṇa & 24. kāyasiddhi & 35. nirvāṇa \\
11. mahāmudrā & 25. vāyusiddhi & 36. [concluding chapter] \\
\hline
\end{tabular}

\footnotetext{
${ }^{a}$ The four types are mṛdu, madhya, adhimātra and adhimātratara. These chapters probably inspired the section on the four types of students in the theta recension of the Amaraughaprabodha
}

Metaphysics, such as the sun, moon and fire, are mentioned only in passing in the Amaraughaprabodha's section on Hațhayoga. Theory regarding matter (prakrti), mind and the five bodily winds is absent. In the chapters of the Amrtasiddhi that follow the practice of the three mudrās (i.e., chapters 11-14), many supernatural effects are enunciated and nearly all of these have been omitted by the redactor of the Amaraughaprabodha. Therefore, it can be generally said that, if the redactor of the Amaraughaprabodha did indeed use the Amrtasiddhi, the process of redacting the section on Hathayoga was reductionist in the extreme and orientated almost entirely towards the practice of physical techniques and the results. This is also characteristic of other early works on Hathayoga. As the physical techniques, which came to define Hathayoga, moved from one tradition to another, the theory underlying them was minimal and subject to syncretization.

The redactor of the Amaraughaprabodha did not altogether omit the terminology and theory that was peculiar to Buddhism. Terms were retained that Śaivas would have understood in contexts of yoga, such as mahāmudrā, ānanda and śünya, on account of their use in earlier Śaiva works. Other terms that could be understood in a general sense, such as vimarda ('pounding') and vicitra ('various'), were also retained. Nonetheless, when this terminology occurs in the Amrtasiddhi, its meaning is specific to a system of four blisses, moments and voids that was unique to esoteric Buddhism. Furthermore, some of Amrtasiddhi's terminology that probably derived from Rasaśāstra, such as vedha, maraṇa and puṭa, was incorporated by the redactor of the Amaraughaprabodha, perhaps because the meaning of these terms was known outside of esoteric Buddhism.

The Śaiva orientation of the Amaraughaprabodha is established by the attribution of its teachings to Gorakșanātha and verses that mention Śiva, Śakti or the linga in the introduction and the sections on Mantra-, Laya-, Hatha- and Rājayoga. Although the redactor integrates terminology and metaphysics of the Amrtasiddhi, the explicit references to Śiva, Śakti and the linga affirm the Śaiva 
orientation of the work. A good example of this is seen in the penultimate verse of the introduction, in which notions of the sun and moon that are central to the teachings of the Amrtasiddhi are subsumed under the goal of uniting Śiva and Śakti above the aperture of the skull (brahmarandhra):

When the lord of thoughts is still and the sun enters completely the path of Meru (i.e., sușumnā); when its fiery state has increased, the moon melts and the body is quickly made full; when an abundance of bliss rises up and the darkness of delusion, such as [the thoughts] 'yours' and 'mine', departs, and when the aperture of the skull bursts open, the extraordinary and unprecedented union of Śiva and Śakti prevails. ${ }^{45}$

The above verse combines the metaphysics of the Amrtasiddhi with those of earlier Śaiva traditions. Moving the sun into the central channel (meru) is mentioned in a passage of the Amrtasiddhi (4.5-10) that describes a process of uniting the sun and moon. The aim of the Amrtasiddhi's yoga is to prevent the sun devouring the moon's nectar. However, rather than conserving the nectar in the moon, the above verse incorporates the different idea of the moon melting and filling the body, presumably, with nectar. The notion of flooding the body with nectar in order to purify and rejuvenate it can be found in early Saiddhāntika works, including the Kiraṇa and Mrgendratantra (Täntrikäbhidhānakośa 2000 vol 1, p. 138). The verse concludes with uniting Śiva and Śakti, rather than the sun and moon. The association of śakti, or more specifically kuṇqalinī, with nectar may not have been new to Śaivas, because a nectarean kundalinī (kunḍalī) is mentioned in the pre-tenth century Sākta scripture, the Tantrasadbhāva (Tāntrikābhidhānakośa 2000 vol 1, p. 136.), ${ }^{46}$ and kuṇdalini is associated with nectar (amrta) in a pre-tenth century Saiddhāntika work, the Sārdhatriśatikālottara (12.1-2). ${ }^{47}$ Also, there is a precedent in the Śaiva work called the Jayadrathayāmala for the practice of a mudrā (karana) that releases nectar and unites Śiva and Śakti. ${ }^{48}$

\footnotetext{
45 Amaraughaprabodha (beta) 13 (nirvāte cittarāje viśati khararucau merumārgam samantād udrikte udrikte vahnibhāve dravati śaśadhare pūrayaty āśu kāye I udyaty ānandavrnde tyajati tavamametyādimohāndhakāre prodbhinne brahmarandhre jayati śivaśivāsañgamah ko 'py apūrvah II 13a nirvāte ]: niryāte Ed. 13 a cittarāje $] \mathrm{G}_{1}, \mathrm{~A}_{2}$ : cittarāte $\mathrm{B}, \mathrm{A}_{2}, \mathrm{G}_{2}, \mathrm{~T}$, Ed. 13 a viśati $] \mathrm{G}_{1}, \mathrm{~A}_{2}$ : vrajati $\mathrm{B}, \mathrm{A}_{2}, \mathrm{G}_{2}, \mathrm{~T}, \mathrm{Ed}$. 13a khararucau ] $\mathrm{B}, \mathrm{A}_{2}, \mathrm{G}_{2}, \mathrm{~T}$, Ed : khararuce $\mathrm{G}_{1}, \mathrm{~A}_{2}$. 13a merumārgam ] $\mathrm{B}, \mathrm{A}_{2}, \mathrm{G}_{2}, \mathrm{~T}, \mathrm{Ed}$ : merudurge $\mathrm{G}_{1}, \mathrm{~A}_{2} .13 \mathrm{~b}$ udrikte ] conj. : udrakte $\mathrm{T}$ : udrajñe $\mathrm{B}, \mathrm{A}_{2}, \mathrm{G}_{2}$ : durvrtte $\mathrm{G}_{1}, \mathrm{~A}_{2}$ : dudrajñe Ed. 13b dravati ] $\mathrm{G}_{1}, \mathrm{~A}_{2}$ : sravati $\mathrm{B}, \mathrm{A}_{2}, \mathrm{G}_{2}, \mathrm{Ed}:+++\mathrm{T}$. $13 \mathrm{~b}$ śaśadhare ] ++++ T. $13 \mathrm{~b}$ pūrayaty āśu kāye ] $\mathrm{B}, \mathrm{A}_{2}, \mathrm{G}_{2}$, Ed : pūrayitvā tu kāyam $\mathrm{G}_{1}, \mathrm{~A}_{2}$ : ++yaty āśu kāye $\mathrm{T}$. udyaty ānandavrnde ] $\mathrm{A}_{2}, \mathrm{G}_{2}, \mathrm{~T}$, Ed : utp +utyānantakande $\mathrm{G}_{1}$ : unnatyānandakande $\mathrm{A}_{2}$ : udayatyānandavrnnde $\mathrm{B}$ (unmetr.). 13c tyajati ] jatyat $\mathrm{A}_{2}$. 13c tava- ] śiva- $\mathrm{A}_{2} .13 \mathrm{c}$-mametyādi ] $\mathrm{A}_{2}, \mathrm{G}_{2}, \mathrm{~T}, \mathrm{Ed}:-$ mamevandi $\mathrm{B}$ : -mukhetyādi- $\mathrm{G}_{1}, \mathrm{~A}_{2} .13 \mathrm{c}$ unnatyānandakande ] ++hāndhakāre $\mathrm{T}$. 13d śivaśivāsañgamah ] $\mathrm{A}_{2}, \mathrm{Ed}$ : śivaśivāsañgamam $\mathrm{B}, \mathrm{T}, \mathrm{G}_{1}$ : śivaśi+samgamaḥ $\mathrm{A}_{2}$ : śivāsañgamam $\mathrm{G}_{2}$ (unmetr.). 13d apūrvah ] apūrvam $\mathrm{B}$.

46 On the date of the Tantrasadbhāva, see Sanderson (2001, p. 4 (n.1), 20-35).

47 See Hatley (forthcoming, pp. 2-3). On the date of this work, see Goodall (2004, p. 1xxxvii).

${ }^{48}$ For the reference and translation of this passage, see Mallinson (2007, p. 21, 177 n. 79). Also, two fourteenth-century works, the Khecarīvidyā (3.1-15) and a section on yoga in the Särngadharapaddhati, contains passages on flooding of the body with nectar by uniting Śiva and Śakti (Mallinson 2007, pp. 28, 131).
} 
Although the Amaraughaprabodha's section on Hathayoga corresponds most closely to the yoga of the Amrtasiddhi, Śaiva terminology and metaphysics have been introduced at key places to give the impression that this is a Saiva form of yoga. In order to demonstrate this, as well as examine other issues around the relationship between the two texts and the Śaiva conception of Hathayoga, I shall compare the descriptions of mahāmudrā and the results of practising it in both texts. The Amaraughaprabodha describes it as follows:

Having pressed the perineum with the left foot and having held the extended right foot with both hands, [the yogin] should breathe in through the mouth. Having fixed the lock in the throat, [the yogin] should hold the breath upwards. Just as a snake hit with a stick becomes [straight] like a stick, so, the coiled śakti [called] kuṇdalinī suddenly becomes straight. Then, she resides in [a vessel] with two halves and has a death-like state. Great afflictions, etc., and problems, such as death, are destroyed. For this reason, the wisest call [it] the 'great mudrā.'49

As depicted in Fig. 2, the yogin in mahāmudrā is in an asymmetrical position, with one leg straight and the other bent. The heel of the bent leg presses against the perineum, his hands hold the foot of the extended leg, over which his torso is folded forward.

If one compares the description of mahāmudrā in the Amaraughaprabodha with the Amrtasiddhi, it is clear that both are describing the same technique but a few of the details and, in particular, the results are quite different. The Amrtasiddhi (11.310) states:

Having pressed the perineum carefully with the heel of the left foot, [the yogin] should hold firmly with both hands the right [foot of the] extended leg. Having put his hips on an āsana [mat], placed the chin on the chest, closed the nine doors [of the body], filled the belly with the breath, he should focus the mind on the crossroads and undertake control of the breath. Having broken the flow of the moon and sun, he should stop the breath. This digests impurity, assimilates semen and the inner resonance, causes prāna to move through all the channels and stimulates the fire [in the body]. By uniting body, speech and mind, mastery of body, speech and mind certainly arises through the practice [of this mudrā] by the yogin who has progressed on the path. Because of this

\footnotetext{
${ }^{49}$ Amaraughaprabodha (beta) 19-22 (pādamūlena vāmena yonim sampị̄̂ya dakșinam I pādam prasāritam dhṛtvā karābhyām pūrayen mukhe ॥19\| kanțhe bandham samāropya dhārayed vāyum

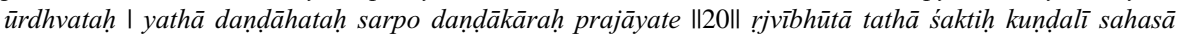
bhavet I tadāsau maraṇāvasthā jāyate dvipuțāśritā $\mid 121 \|$ mahākleśádayo doṣā bhidyante maraṇādayah | mahāmudrām tu tenaiva vadanti vibudhottamāh $\|22\| 19 \mathrm{c}$ pādam prasāritam $] \mathrm{G}_{1}, \mathrm{~A}_{2}$ : prasāritam padạ̣ $\mathrm{A}_{1}, \mathrm{G}_{2}, \mathrm{~T}, \mathrm{Ed}$ : prasāritam pada $\mathrm{B} .19 \mathrm{c}$ dhrtvā ] $\mathrm{G}_{1}, \mathrm{~A}_{2}: k r t v \bar{a} \mathrm{~B}, \mathrm{~A}_{1}, \mathrm{G}_{2}, \mathrm{~T}$, Ed. 19d mukhe ] mukham $\mathrm{B}$. 20a kanțthe ] kanțham B. 20a bandham ] baddham T. 20a-b samāropya dhārayed ] $\mathrm{G}_{1}, \mathrm{~A}_{2}$ : samāropya krdhārād $\mathrm{A}_{1}$ : samāropyādhārād $\mathrm{G}_{2}, \mathrm{~T}$, Ed : samāropya cādhāratad $\mathrm{B}$ (unmetr.). 20c sarpo ] sarvo $\mathrm{B}$. 20d

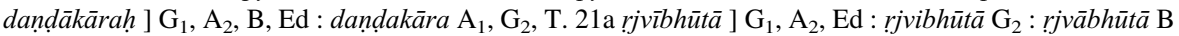
: rijyabhūtā $\mathrm{A}_{1}$ : ryja++ T. 21a tathā $] \mathrm{G}_{1}, \mathrm{~A}_{2}$ : tadā $\mathrm{B}, \mathrm{A}_{1}, \mathrm{G}_{2}, \mathrm{Ed}:++$ T. śaktih ] $\mathrm{G}_{1}, \mathrm{~A}_{2}$, Ed : śakti- $\mathrm{B}$, $\mathrm{A}_{1}, \mathrm{G}_{2}$, T. 22a mahākleśádayo doṣā ] $\mathrm{G}_{1}$ : mahākleśādayo doṣāh $\mathrm{A}_{2}$ : mahārogā mahākleśā $\mathrm{B}, \mathrm{A}_{1}, \mathrm{G}_{2}, \mathrm{~T}$, Ed. $22 \mathrm{~b}$ bhidyante $] \mathrm{G}_{1}, \mathrm{~A}_{2}$ : jïryante $\mathrm{B}, \mathrm{A}_{1}, \mathrm{G}_{2}, \mathrm{~T}$, Ed. 22c tu $\mathrm{G}_{1}, \mathrm{~A}_{2}:$ ca $\mathrm{B}, \mathrm{G}_{2}, \mathrm{~T}, \mathrm{Ed}$ : ci $\mathrm{A}_{1}$. 22c tenaiva ] $\mathrm{G}_{1}, \mathrm{~A}_{2}, \mathrm{~B}$ : tenainām $\mathrm{A}_{1}, \mathrm{G}_{2}, \mathrm{~T}, \mathrm{Ed} .22 \mathrm{~d}$ vibudhottamāh ] hi budhottamāh $\mathrm{B}$.
} 


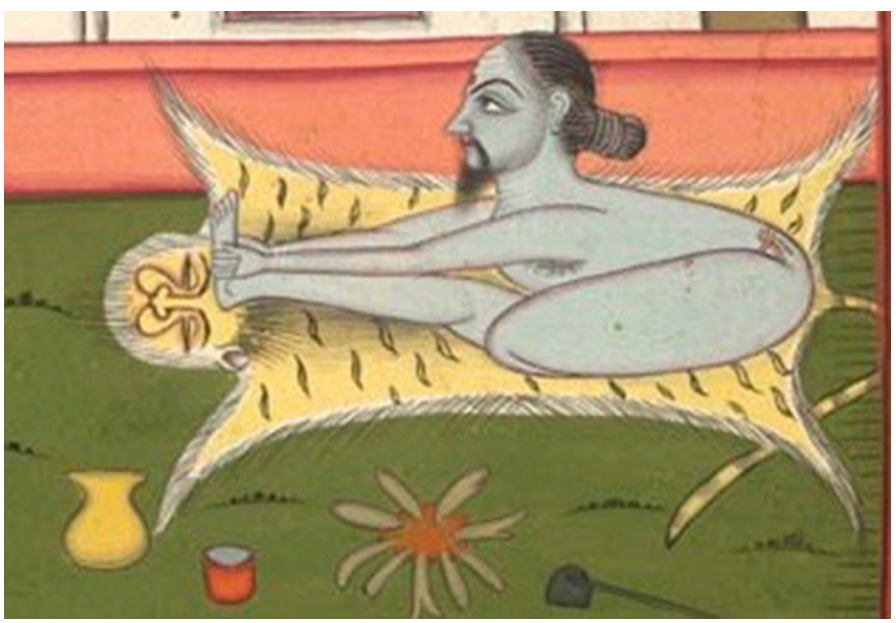

Fig. 2 Detail of mahāmudrā āsana, Ms. no. Add 24099 (f. 16). British Library Trust. Published in Bühnemann 2007: 46

$m u d r \bar{a}$, everything [good] is sure to arise for a yogin. Therefore, one should diligently practice this great mudrā. Of all the mudrās, it is great and independent. Therefore, the best of the wise call it the 'great mudrā.' Death is held in check by it. Therefore, it is always beneficial. The exercise (yantra) is mastered by one whose mind is concentrated. ${ }^{50}$

When these two passages are placed side by side, as in Table 6, the most conspicuous difference is that the Amaraughaprabodha is more succinct and uses different syntax and terminology.

Furthermore, the Amaraughaprabodha has the additional instruction that the yogin should breathe in through the mouth (highlighted in bold in Table 6), and several other directives are missing, such as focusing the mind on the crossroads (catuhpatha). These significant differences raise the question of whether the redactor of the Amaraughaprabodha used the Amrtasiddhi or some other (currently unknown) source to redact the section on Hathayoga. If it was the Amrtasiddhi, then the redactor radically truncated and modified the Amrtasiddhi's account of mahāmudrā. Some of the added details and omissions might be explained by variations or alternative views of the practice. However, it is more difficult to

\footnotetext{
50 Amrtasiddhi 11.3-10 (yonim sampīạya vāmena pādamūlena yatnatah I savyam prasāritam pādam karābhyām dhārayed dṛ̣ham \|3\| āsane kațim āropya cibukam hṛdayopari I nava dvārāṇi samyamya kukșim āpūrya vāyunā \|4\| cittạ̣ catuhpathe kṛtvā ārabhet prāṇayantraṇam I candrārkayor gatịn bhañktvā kuryād vāyunivāranam \|5\| jāraneyam kașāyasya cāranam bindunādayoh I cālanam sarvanādịnām analasya ca dīpanam \|6\| kāyavākcittayogena kāyavākcittasādhanam | bhaved abhyāsato 'vaśyam mārgārūẹhasya yoginaḥ $\|7\|$ anayā mudrayā sarvam jāyate yogino dhruvam I tasmād enām prayatnena mahāmudrām samabhyaset $\|8\|$ sarvāsām eva mudrānạ̄̄ mahatīyam svayaṃbhuvā । mahāmudrāṃ ca tenainām vadanti vibudhottamāḥ $\|9\|$ anayā bādhyate mṛtyur hiteyam tena sarvadā । cetasā vidhr̂̀̄ yena yantram tenaiva nirjitam).
} 


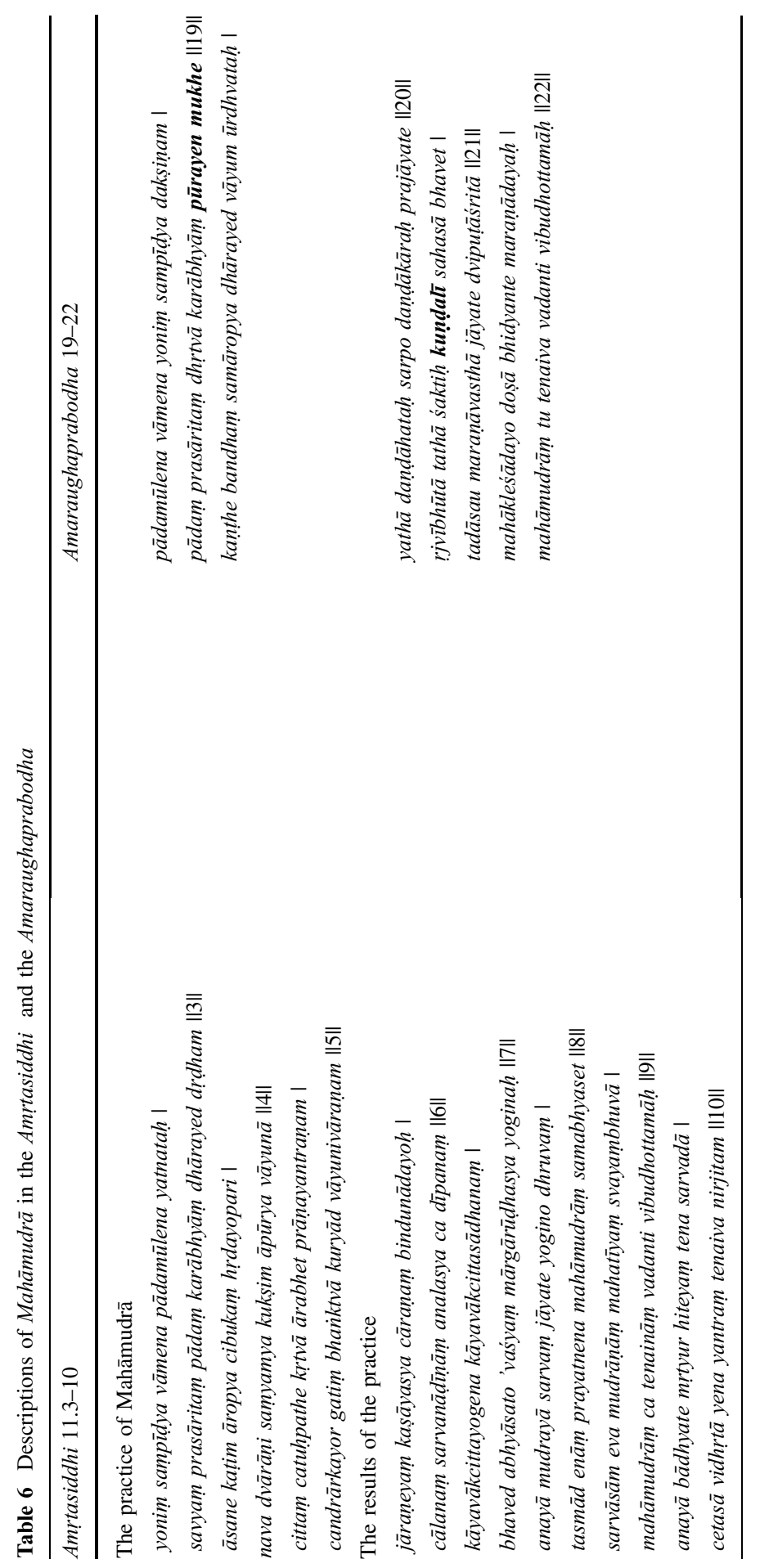


propose reasons for why a redactor would truncate the Amrtasiddhi's account to the extent seen in the Amaraughaprabodha.

Indeed, it seems possible, if not probable, that the Amaraughaprabodha has preserved an older and more rudimentary account of this yoga than that of the Amrtasiddhi. One might further propose that this older work was a source text for the Amrtasiddhi, because the latter has verses in common with the Amaraughaprabodha. Even if the Amaraughaprabodha's teachings on Hathayoga derive from a text that was older than the Amrtasiddhi, the original source must have been composed in a Vajrayāna milieu because the remnants of this tradition's distinct system of four blisses, voids and moments are apparent in the Amaraughaprabodha. Therefore, the most significant change made by the redactor of the Amaraughaprabodha to the description of mahammudrā was the introduction of the Saiva metaphysics of kundalinī (highlighted in bold in Table 6).

In the Amaraughaprabodha, mahāmudrā is likened, in effect, to a stick that is used to kill a snake. It strikes the coiled kundalini and forces her to become straight. Such notions of force, as well as the metaphysics of kundalinī, are absent in the Amrtasiddhi. So, it would seem that Saivas understood the notion of force (hatha) in Hathayoga as referring to the forceful effect of its practice on kundalinī. This understanding probably extended to the general aim of the three mudrās, which was to force kuṇdalinī and prāna up through the central channel to pierce the three knots (granthi). Similar forceful effects, in particular on apānavāyu, semen and kuṇdalin̄i, can be found in other early works on Hathayoga and, in my opinion, provide the strongest indication for the intended meaning of hathayoga in the formative phase of this type of yoga (Birch 2011, pp. 544-545).

Both the Amaraughaprabodha and the Amrtasiddhi use terms from Rasaśāstra, such as jāraṇa ('digesting') and cāraṇa ('assimilating'), to describe the effects of mahāmudrā. In the Amaraughaprabodha's description, the pressing of the perineum and the application of the throat lock (bandha) seem to create something akin to an alchemical vessel with two halves or lids (dviputa). ${ }^{51}$ Presumably, this vessel is the central channel after it has been blocked above and below by the locks, which envelop and hold kuṇdalinī in a death-like state (maraṇāvasthā). Although the meaning of marañavasth $\bar{a}$ is not entirely clear to me in the context of raising kuṇdalin̄ to meet Ś Siva in or above the brahmarandhra, it seems that the redactor may have been alluding to the process of 'killing' (māraṇa), which in Rasaśāstra refers to heating a substance in a burning pit (puta) until it turns to ash. ${ }^{52}$ These

\footnotetext{
51 I am assuming here that the term puta is referring more specifically to a vessel or burning pit, rather than the process of heating a metal, which involves a pit, an enclosed vessel and fuel for the fire (puțapāka). Hellwig (2009, p. 307) states that both meanings are possible but can be difficult to distinguish in texts: "Die Erhitzung mit puțas, der puțapāka, ist eine zentrale Verfahrensweise der indischen Alchemie. Da sich Vorgangsbezeichnung (puțapāka) und praktischer Aufbau (puța) an den meisten Fundstellen nicht unterscheiden lassen und der Begriff puṭa für beide Konzepte benutzt wird, werden sie in einem Artikel behandelt." I would like to thank James Mallinson for this idea and the reference.

52 "Trotz oder gerade wegen seiner enormen Bedeutung für die indische Alchemie wird das mārana ("Töten“) nicht formal definiert. Zentrales Element aller mārana-Vorschriften ist aber das Erhitzen einer Substanz, in dessen Verlauf diese Substanz in ein bhasman ("Asche“) transformiert wird." (Hellwig 2009, p. 238).
} 
alchemical metaphors, which are also found in the Amrtasiddhi, imply that kundalini is transformed irreversibly from her coiled to erect state in the central channel. ${ }^{53}$

The Amaraughaprabodha's description of the second mudrā called mahābandha includes two metaphysical terms, namely triveñ $\bar{a}$ and kedāra, that do not occur in the

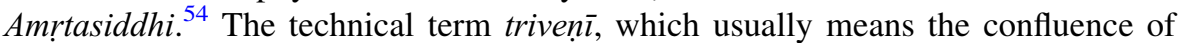
the three main channels in other Hatha- and Rājayoga texts, ${ }^{55}$ would probably have been known to a Śaiva audience judging by its appearance in earlier Śaiva works, such as the Kubjikāmatatantra, in which it is mentioned along with the channels (5.170-72) and located in the navel (25.93). The Kuñcitänghristava, which was composed in Cidambaram in the fourteenth century, locates it in the heart. This confluence, also known as the prayāga, was considered one of eight sacred places in early Śaivism, as attested in works such as the Niśvāsaguhya (1.29-34) and the Tantrasadbhāva (15.62). ${ }^{56}$ Kedāra, which is generally located in the head, ${ }^{57}$ is included in lists of forty sacred sites (tîrtha) in "the Śivadharma and throughout the scriptural authorities of the Mantramārga" (Sanderson 2003, p. 405). ${ }^{58}$ Both these terms appear to have been added by the redactor of the Amaraughaprabodha to make the practice of mahābandha appeal to a Śaiva audience.

The account of mahāvedha in the Amaraughaprabodha does not introduce terminology that is peculiar to Śaivism and absent in the Amrtasiddhi. In fact, the challenge the redactor appeared to face in composing the remaining portion of the section on Hathayoga was modifying or removing concepts unique to Buddhism, in particular the technical terms from the sexual yoga of some Vajrayāna works, which incorporate systems of four blisses, moments and voids (Sferra 2000, pp. 31-33), as seen in Table 7.

\footnotetext{
53 I wish to thank James Mallinson for pointing out to me the meaning and implications of this alchemical terminology in the Amaraughaprabodha, which occurs in the Amrtasiddhi in the passage translated above as well as 14.14ab. Until now, I have been inclined to understand Amaraughaprabodha (beta) $21 \mathrm{~cd}$ as later commentators did (see below). I also wish to thank Dagmar Wujastyk for her comments on this hemistich and its alchemical metaphors.
}

54 Amaraughaprabodha (beta) 25: "And this [mahäbandha] stops the upward flow of [air in] all the channels. It places the mind on the confluence of the three [main] currents and causes it to reach Kedāra (ayañ ca sarvanād̄̄nām ūrdhvamgatinirodhakah I triven̄isañgamam dhatte kedāram prāpayen manah). Amaraughaprabodha (beta) 25ab Amrtasiddhi 12.15ab (bandho 'yam sarvanādīnām ūrdhvagatinirodhakah) and Amaraughaprabodha (beta) $25 \mathrm{~cd}$ is untraced.

55 The term triveñ̄ is used in the Śivasamhitā (5.169-172) to refer to the confluence of the Gangā, Yamunā and Sarasvatī rivers, which are equated with $i d \underline{a}$, pingalā and the central channel, respectively. In the Yogaprakāśikā (5.27), Bālakṛṣna gives the same information (iḍāitritayarūpiṇi yā triveṇi gamgāyamunāsarasvatīrūpā tayā prānavāyoḥ sambandham [...]). The Gheraṇdasamhitā (5.88) locates it in the nostrils.

56 I wish to thank Somadeva Vasudeva for these references (p.c. 19.4.2018).

57 In the Jābāladarśanopanișat (48), Kedāra is located in the forehead (lalātaka). In the Jyotsnā (3.24), Brahmānanda locates it between the eyebrows as Śiva's abode (kedāram bhruvor madhye śivasthānam kedāraśabdavācyam tam manah svāntam prāpayet). In the Khecarīvidyā, it is located at the cülitala, which is at the back of the head and above the nape of the neck (Mallinson 2007, p. 214 n. 285). In the Yogaprakāsikā (5.27), Bālakṛṣna equates it with the brahmarandhra. The same location is found in the Gorakh Bāṇ̄ (p. 256, section 19).

58 Prayāga would refer to the confluence of sacred rivers in Allahabad and kedāra to Kedarnath in the Indian Himalayas. 
Table 7 Blisses, moments and voids in Vajrayāna

\begin{tabular}{lll}
\hline Blisses & Moments & Voids \\
\hline ānanda & vicitra & śūnya \\
paramānanda & vipāka & atiśūnya \\
viramānanda & vimarda & mahāśūnya \\
sahajānanda & vilakșaṇa & sarvaśūnya \\
\hline
\end{tabular}

The Amrtasiddhi incorporates this terminology, with the exception of viramānanda, vilakșanakșana and sarvaśūnya. The Amaraughaprabodha does not mention the four moments at all, but includes three blisses and voids. Although this specific system of blisses and voids may be unique to Vajrayāna, terms such as ānanda, paramānanda, śūnya and mahāśūnya are scattered throughout Śaiva works. Furthermore, some Śaivas were probably familiar with progressive stages of sounds and void-like meditative states in their own tradition. ${ }^{59}$ Therefore, it would seem that the redactor of the Amaraughaprabodha deliberately excluded terminology that was specific to Vajrayāna, but was willing to include terms that occur in Saiva works. This strategy is evident in a comparison of the following parallel passages of the Amrtasiddhi and the Amaraughaprabodha. In the first example, the vicitra moment has been emended to a 'vicitra' sound:

The Amrtasiddhi:

When the first stage is completed and Brahmā's knot pierced, then, a biting [sensation] and the perception of a little bliss in the central channel arise. One also enters into voidness and the vicitra moment arises. ${ }^{60}$

The Amaraughaprabodha:

Because of piercing Brahmā's knot, bliss arises in the void. The unstruck resonance, which has various [musical] sounds (vicitrakvanaka), is heard in the body. ${ }^{61}$

Whether the redactor of the Amaraughaprabodha was responsible for this unobtrusive emendation is not certain because the south-Indian manuscripts of the Amrtasiddhi also preserve vicitrakvana, which is one of many instances where the Indian transmission has changed technical terms of Vajrayāna into something

\footnotetext{
59 For a discussion of internal sounds and void-like meditative states, see Vasudeva (2004, pp. 263-271, 336-342).

60 Amṛtasiddhi 19.14-15ab (ekāvasthā yadā pūrṇā vedho 'yam brahmagranthitaḥ I tadā daṃso bhaven madhye kị̣cidānandadarśanam II śūnyatānupraveśo 'pi vicitrakṣaṇasambhavam).

61 Amaraughaprabodha (beta) 35 (brahmagranthes tathā bhedād ānandah śünyasambhavah I vicitrakvanako dehe 'nāhatah śrūyate dhvanih $\| 35 \mathrm{a}$-granthes tathā $] \mathrm{G}_{1}$ : -graje satato $\mathrm{A}_{2}$ (unmetr.) : -granther bhaved $\mathrm{B}, \mathrm{A}_{1}, \mathrm{G}_{2}, \mathrm{~T}$ : -granthe bhaved Ed. $35 \mathrm{a}$ bhedād $] \mathrm{G}_{1}, \mathrm{~A}_{2}$ : vedhād $\mathrm{G}_{2}$, Ed : vedhā $\mathrm{B}, \mathrm{A}_{1}$, T. $35 \mathrm{~b}$ ānandah śūnyasambhavah ] $\mathrm{G}_{1}, \mathrm{~A}_{2}, \mathrm{~A}_{1}, \mathrm{G} 2, \mathrm{~T}$ : nandah̆ śūnyasambhavah $\mathrm{B}$ (unmetr.) : ānandā+nyasambhavam Ed. 35c -kvanako ] $\mathrm{B}, \mathrm{A}_{1}, \mathrm{G}_{2}, \mathrm{~T}, \mathrm{Ed}$ : -kvaṇiko $\mathrm{G}_{1}$ : -kvako $\mathrm{A}_{2}$ (unmetr.). $35 \mathrm{~d}$ 'nāhatah ] $\mathrm{A}_{1}, \mathrm{G}_{2}, \mathrm{~T}$ : nāhatah $\mathrm{Ed}$ : 'nāhate $\mathrm{A}_{2}$ : nāhate $\mathrm{G}_{1}$ : 'nvāhata $\mathrm{B}$ ).
} 
more intelligible to non-Buddhist yogins. ${ }^{62}$ Therefore, it is possible that vicitrakșana had already become vicitrakvana in a south-Indian version of the Amrtasiddhi by the time the Amaraughaprabodha was written. ${ }^{63}$

In another example, the redactor of the Amaraughaprabodha removed the reference to the vimarda moment by omitting the word for moment (kșana). In this case, vimarda would have been understand by a non-Buddhist in its more general sense of 'pounding':

The Amrtasiddhi:

[...] When the second stage is complete, the [state] beyond the void arises. Then, the sound of the bheri drum occurs in the middle channel and the vimarda moment. ${ }^{64}$

\section{The Amaraughaprabodha:}

[...] Then, because of piercing Viṣnu's knot, a pounding [sound] (vimarda), which is indicative of supreme bliss, arises beyond the void. Then, the sound of a bherī drum occurs. ${ }^{65}$

It is worth asking why the redactor of the Amaraughaprabodha retained any of the Amrtasiddhi's technical terminology peculiar to Vajrayāna, given that less ingenuity would have been required to remove it altogether. For example, one might question the need of a verse at the end of the description of mahāvedha in the Amaraughaprabodha, which states that the yogin should know the conjunction of the moon, sun and fire in order to achieve immortality. ${ }^{66}$ These metaphysical notions are important in the Amrtasiddhi, but none are mentioned elsewhere in the Amaraughaprabodha's section on Hathayoga. The inclusion of this verse, as well as terms like vicitra and vimarda, suggests that the intended audience of the Amaraughaprabodha was familiar with the Buddhist origins of this yoga. Therefore, although the redactor of the Amaraughaprabodha may have composed the text to lay claim to Hathayoga as a Saiva practice, it seems that the system of blisses, voids and sounds could not be dispensed with entirely, perhaps because this type of Vajrayāna yoga was still known at the time of writing. The likelihood of this and the possibility that the redactor was using a more rudimentary version of the Amrtasiddhi points to an early date (i.e., the twelfth century) for the composition of the short recension of the Amaraughaprabodha. Be this as it may, it seems that the short recension of the Amaraughaprabodha was composed close to the time of the Amrtasiddhi, when the yoga of the latter was still known, especially in communities transitioning from

\footnotetext{
${ }^{62}$ For a discussion and more examples of such changes, see Mallinson (2016b).

63 I would like to thank Dominic Goodall for pointing this out to me.

64 Amṛtasiddhi 20.7 (sampūrṇāyām dvitīyāyām atiśūnyam prajāyate I bherīsiabdas tadā madhye vimardakșañasambhavah).

65 Amaraughaprabodha (beta) 38 (viṣnugranthes tato bhedāt paramānandasūcakah $\mid$ atiśūnye vimardaś ca bheríśabdas tato bhavet \| 38a tato ] $\mathrm{G}_{1}, \mathrm{~A}_{2}$ : tathā $\mathrm{B}, \mathrm{A}_{1}, \mathrm{G}_{2}, \mathrm{~T}$, Ed. 38a bhedāt $\mathrm{A}_{2}$ : vedhāt $\mathrm{G}_{2}, \mathrm{~A}_{1}, \mathrm{~T}$, $\mathrm{Ed}$ : om. B (unmetr.). atiśūnye ] $\mathrm{A}_{1}, \mathrm{G}_{2}, \mathrm{~T}, \mathrm{Ed}$ : atiśūnyo $\mathrm{G}_{1}, \mathrm{~A}_{2}$, B. 38d bherīśabdas ] bherīnādas $\mathrm{A}_{2} .38 \mathrm{~d}$ tato ] $\mathrm{G}_{1}, \mathrm{~A}_{2}$ : tathā $\left.\mathrm{B}, \mathrm{Ed}: \operatorname{tad} \bar{a} \mathrm{~A}_{1}, \mathrm{G}_{2}, \mathrm{~T}\right)$.

66 Amaraughaprabodha (beta) 30ab (somasūryāgnisaṃbandham jānīyād amṛtāya vai $\mid$ 30a -saṃbandham ] $\mathrm{A}_{1}, \mathrm{G}_{2}, \mathrm{~T}, \mathrm{Ed}$ : -saṃbandhā $\mathrm{B}$ : -sambandhāj $\mathrm{G}_{1}, \mathrm{~A}_{2} .30 \mathrm{~b}$ jānīyād ] dāniryyād $\left.\mathrm{B}\right)$.
} 
Buddhism to Śaivism. ${ }^{67}$ This supports James Mallinson's proposal (2016b, p. $11 \mathrm{n}$. 25 and forthcoming) that the Amaraughaprabodha was composed in such a community at Kadri in Karnataka, owing to the text's opening invocation to the wise Siddhabuddha, a disciple of Matsyendranātha from that locality.

Apart from introducing Śaiva terms and metaphysics and obscuring or omitting Vajrayāna ones, the Śaiva appropriation of the Amrtasiddhi's yoga is achieved by making it subordinate to Rājayoga. This so-called 'king of all yogas' probably had an older association with Śaivism, as evinced by a Śaiva work known as the Amanaska, which teaches the attainment of the no-mind state by the practice of śämbhavi mudrā. The Amanaska was known in Gujarat in the mid-twelfth century (Birch 2014, p. 406 n. 21), so it was probably composed in the eleventh or early twelfth century. The redactor of the Amaraughaprabodha alludes to the Śaiva origins of Rājayoga by referring to the linga in the final verse on Rājayoga, ${ }^{68}$ and by defining the term amaraugha (literally, 'a flood of nectar' or 'a multitude of immortals') as Rājayoga. ${ }^{69}$ It is likely that the term amaraugha would have reminded Śaivas of the divine stream of teachings known as the divyaugha in earlier Kaula scriptures, ${ }^{70}$ while also conveying meanings close to that of amrtasiddhi ("the attainment of nectar/immortality'). Moreover, any association Hathayoga might have had with Buddhism when the Amaraughaprabodha was composed would surely not have deterred Śaivas from adopting a system of yoga in which Hathayoga was only one option of several auxiliary methods for the attainment of Rājayoga.

Furthermore, the redactor of the Amaraughaprabodha appears to have distanced Hathayoga from the yoga of the Amrtasiddhi by omitting any mention of semen (bindu) in the section on Hathayoga. In keeping with the sexual yoga of the Kālacakra tradition (Sferra 2000, p. 32), the Amrtasiddhi is very much concerned with retaining semen. An introductory verse of the Amaraughaprabodha states that there are two types of Hathayoga: one practised with the internal resonance (nāda) and the other with semen $($ bind $u){ }^{71}$ Although the yogin is advised to avoid frequenting fire, women and roads in the initial stage of practice, ${ }^{72}$ the emphasis on internal sounds and the absence of references to semen indicate that the first type of Hathayoga, rather than the second, was taught. A further distinction can be seen in the way both works interpret nectar. In the Amaraughaprabodha, nectar (amara) is

\footnotetext{
67 See Mallinson (2016b) for information on the Buddhist milieu in which the Amrtasiddhi was probably composed.

68 Amaraughaprabodha (beta) 44a: "[For the Rājayogin,] that into which the universe is easily dissolved is called [Śiva's] Linga" (līnam yatra carācaram sukhavaśāt tal lingam ity ucyate | 44a yatra ] yatri $\mathrm{A}_{1}$. 44a sukhavaśāt ] $\mathrm{G}_{1}, \mathrm{~A}_{2}$ : layavaśāt $\mathrm{B}, \mathrm{A}_{1}, \mathrm{G}_{2}, \mathrm{~T}$, Ed. 44a. tallingam ] talyamgam $\mathrm{A}_{2}$ ).

69 Amaraughaprabodha (beta) 14ab: "Only this unique amaraugha has the name Rājayoga" (eka evāmaraugho 'yam rājayogābhidhānakah | 14a evāmaraugho 'yam ] emend. : evāmaraugho yam $\mathrm{G} 1, \mathrm{~A} 2$ : evāmarogho hi B, A1, G2, T : evāmaraugho hi Ed. 14b -dhānakaḥ B, A1, G2, T, Ed : -dhānakaṃ G1, A2).

70 I am grateful to Somadeva Vasudeva for pointing this out to me. For more information on divyaugha, see the Tāntrikābhidhānakośa vol 3 (2013, p. 168).

71 Amaraughaprabodha (beta) 4cd (hațho 'pi dvividhah prokto nādabinduniṣevañāt I 4c dvividhah ] B, $\mathrm{A}_{1}, \mathrm{G}_{2}, \mathrm{~T}, \mathrm{Ed}$ : dvividhā $\mathrm{G}_{1}$ : dvividhāh $\mathrm{A}_{2} .4 \mathrm{c}$ prokto ] $\mathrm{G}_{1}, \mathrm{~A}_{2}$ : kvāpi $\mathrm{B}_{1}, \mathrm{~A}_{1}, \mathrm{G}_{2}, \mathrm{~T}$, Ed. 4d nāda- ] $\mathrm{G}_{1}$ : rāda- $\mathrm{A}_{2}: v \bar{a} y u-\mathrm{B}, \mathrm{A}_{1}, \mathrm{G}_{2}, \mathrm{Ed}: v \bar{a}+\mathrm{T} .4 \mathrm{~d}$-bindunișevaṇāt $\left.]+++++++\mathrm{T}\right)$.

72 Amaraughaprabodha (beta) 33cd: "[The yogin] should avoid at first frequenting fire, women and roads" (vahnistrīpathasevānām ādau varjanam ācaret $\| 33 \mathrm{c}$-patha- ] $\mathrm{A}_{2}, \mathrm{~A}_{1}, \mathrm{G}_{2}, \mathrm{~T}, \mathrm{Ed}$ : -padha- B : -pathi- $\mathrm{G}_{1}$ ).
} 
associated with Rajjayoga, which is defined as meditative absorption, whereas in the Amrtasiddhi nectar (amrta) corresponds with semen in the male body. ${ }^{73}$

Some of the metaphysics and terminology specific to the Amrtasiddhi continued to be used by authors of works on Hathayoga up until the nineteenth century, partly because of the significant amount of verses that Svātmārāma borrowed from the Amaraughaprabodha's section on Hathayoga. The passage on the four stages of yoga, in which the knots are pierced and various blisses, sounds and voids arise, was incorporated into the fourth chapter of the Hathapradipik $\bar{a}$ as the practice of nādānusandhāna ('fusing the mind with the internal resonance'). ${ }^{74}$ In other cases, the original meaning of the technical terminology was lost and reinterpreted. For example, the alchemical terms dviputa and putadvaya have been interpreted by commentators as dvināsāputa ('the two nostrils') and the channels iḍa and pingala ${ }^{75}$ In the Yogacintāmaṇi, Śivānanda rewrote the verse on kundalinī to say that she destroys the state of death, and Bhavadeva interpreted it to mean that, after the practice of mahāmudrā, kundalinī resides in the two nostrils. ${ }^{76}$ Furthermore, it is likely that Svātmārāma and others understood a verse on the conjunction of the moon, sun and fire as referring to the intersection of the channels called id a , pingalā and sușumna $\bar{a}^{77}$ because this meaning of moon, sun and fire can be found in early Śaiva works and even two yoga texts, the Vivekamārtaṇda and the Śivasaṃitā, known to him. ${ }^{78}$

\section{Conclusion}

The relationship between the Amrtasiddhi and the beta recension of the Amaraughaprabodha provides a window onto the early history of Hathayoga, which was shaped significantly by the exchange of ideas and techniques between Buddhism and Śaivism in

\footnotetext{
73 Amaraughaprabodha (beta) 3d, 42ab: "Rājayoga is that [state] which is free of mental activity. [...] Then, having become one [with the flute-like sound], the mind is called Rājayoga" (yaś cittavrttirahitah sa tu rājayogah $\|[\ldots]$ || ekībhūtam tadā cittam rājayogābhidhānakam | $42 \mathrm{~b}$ rājayogābhidhānakam ] $\mathrm{G}_{1}, \mathrm{~B}$, $\mathrm{A}_{1}, \mathrm{G}_{2}$, Ed : rājayogo 'bhidhīyate $\mathrm{A}_{2}$ : ++yogā hi dhānakam T). Also see footnote 67.

74 Hațapradīpikā 4.69-77 = Amaraughaprabodha (beta) 34-42.

75 After quoting on mahāmudrā from the Hațapradīpikā, Bhavadeva glosses dvipuțāśritā as nāsāpuțadvayāśritā (Yuktabhavadeva 7.187). In the Jyotsnā (3.27), Brahmānanda glosses puțadvaya as putayor dvayam iḍāpingalayor yugmam.

76 Yogacintāmani, p. 133; "Then she destroys the state of death, which is the basis of adversity" (tathāsau marañāvasthām harate vipadāśrayām). A similar reading is found in an eighteenth-century recension of the Hațapradīpikā with ten chapters (5.17ab) (tadā sā maraṇāvasthā harate dvipuțāśritāa). A commentary on this text, the Yogaprakāsiki $\bar{a}$ (5.17) understands this as mahāmudrā destroying the state of death which resides in the two nostrils (yadā kundalinībodhasamaye vāyor bahir nirgamanam antah praveśa iti yat puțadvayam tam āśritām maraṇāvasthām harate mahāmudreti bhāvah). In Yuktabhavadeva 7.187, Bhavadeva says, "When the retention of the breath is being done thus, kundalini becomes agitated and resides in the two nostrils along with apāna and prāna" (evam vāyudhāraṇāyām kriyamānāāām vyākulā bhūtā kuṇ̣alin̄i apānaprānāāhyām saha nāsāpuṭadvayāśritā bhavati).

77 Amaraughaprabodha (beta) 30ab (somasūryāgnisaṃbandham jānīyād amṛtāya vai I 30a -saṃandham ] $\mathrm{A}_{1}, \mathrm{G}_{2}, \mathrm{~T}, \mathrm{Ed}$ : -saṃbandhā $\mathrm{B}$ : -saṃbandhāj $\mathrm{G}_{1}, \mathrm{~A}_{2} .30 \mathrm{~b}$ jānīyād ] dāniryyād $\mathrm{B}$ ).

78 In the context of nā $\bar{d} \bar{\imath} \mathrm{s}$, references to somasüryāgni occur in the Tantrasadbhāva (24.141) and Svacchandatantra (7.153-154). Also, see Vivekamārtạ̣̣a 20-21 and Śivasamhitā 2.17. In Jyotsnā 3.28, Brahmānanda understands them in this way (somaś ca sūryaś cāgniś ca somasūryāgnayaḥ, somasūryāgniśabdais tadadhișthitā nāḍa iḍāpingalāsuṣumnāgrāhyās teșām sambandhah).
} 
south India around the 11th and 12th centuries. It seems that some sects associated with these religions devised physical methods of yoga on the understanding that prāna could be deliberately manipulated within the body to attain samādhi and liberation with greater efficacy and certainty than other methods. Even though proponents claimed that Hathayoga would cure diseases, old age, suffering, death and so on, ${ }^{79}$ the notion that forcefully manipulating prāna was dangerous (Birch 2011, pp. 538-539), as well as broader trends toward gnosis and ritual in these religions, may have prevented this type of yoga from becoming a central teaching of Śaivism or Vajrayāna. Nonetheless, Hathayoga evolved as an auxiliary practice in systems of yoga associated with Gorakșanātha.

Comparing the Amaraughaprabodha with the Amrtasiddhi reveals that the doctrine and metaphysics used to teach a physical yoga practice could change significantly from one tradition to another, while the physical techniques remained essentially the same. Furthermore, although the physical practice of the Amrtasiddhi's yoga is the same as that of the Amaraughaprabodha, only a fraction of the former's underlying doctrine was adopted by the latter. Physical yoga could be taught with minimal doctrine, and the transposition of its techniques from one sect to another was probably a contributing factor to the doctrinal simplicity of early Hathayoga, which relied upon basic ideas that were extracted from Vajrayāna and Śaivism. Its simplicity would have made it easy to disseminate and adapt for people of various religions and social circumstances, which might explain why its teachings endured for most of the second millennium. A core group of physical techniques, in particular the mudrās and bandhas, came to define Hathayoga, across sectarian divides, throughout its history and made it a unique method for achieving samādhi and liberation.

The short recension of the Amaraughaprabodha is probably the earliest work to combine Hatha- with Rājayoga and it likely predates the Dattātreyayogaśāstra (13th century), which is a more syncretic text, by at least a century. The number and sophistication of physical techniques associated with Hathayoga gradually increased in the centuries following the Amaraughaprabodha, but the doctrine and theory remained simple until shortly after the Hathapradipika, when Hathayoga was absorbed by Brahmanical traditions. This resulted in the physical practices being merged with more complex systems of the subtle body and philosophical teachings from Pātañjalayoga, Vedānta and Tantra. Thus, by the eighteenth century, some erudite Brahmins were writing large compendiums on Hathayoga, such as the Hathasanketacandrikā, and others composed encyclopaedic digests on yoga that incorporated the distinct methods of Hathayoga. Also, at this time, Upanișads based on Hațhayoga texts were created and references to Hațhayoga appeared in commentaries on the Pātañjalayogaśāstra, such as Vijñānabhikṣu's Yogavārttika and Nārāyaṇatīrtha’s Yogasiddhāntacandrikā. This process of assimilation marked the decline of Hathayoga as a distinct method, insofar as its physical techniques and its emphasis on bodily health had become essential components of more general notions of yoga in the modern period.

Acknowledgements I would like to thank (in alphabetical order) Jacqueline Hargreaves, James Mallinson and Mark Singleton for their incisive comments on earlier drafts of this article. Also, lengthy private discussions that I have had with Dominic Goodall, James Mallinson and Somadeva Vasudeva have greatly

\footnotetext{
79 These benefits and more are mentioned in the section on Hathayoga in the beta recension of the Amaraughaprabodha (e.g., 22ab, 23cd, 31, 32, 36, 37cd and 40cd).
} 
helped me to understand the content of the Amaraughaprabodha and the differences between its two recensions. Reading both recensions at a Hatha Yoga Project workshop (15-18.1.2018) at the École française d'Extrême-Orient in Pondicherry with Christèle Barois, Alberta Ferrario, Dominic Goodall, Viswanatha Gupta, Jacqueline Hargreaves, Shaman Hatley, Nirajan Kafle, Murali Krishnan, James Mallinson, SAS Sarma, Mark Singleton and Somdev Vasudeva deepened my understanding of the text and enabled me to solve many problems in my critical editions and translations of both recensions. Also, thanks to James Mallinson and Péter-Dániel Szántó for sharing with me a draft of their critical edition of the Amrtasiddhi. My work on this article has received funding from the European Research Council (ERC) under the European Union's Horizon 2020 research and innovation programme (Grant Agreement No. 647963). My critical edition and translation of the Amaraughaprabodha will be published as one of the outputs of the Hatha Yoga Project in 2020.

Open Access This article is distributed under the terms of the Creative Commons Attribution 4.0 International License (http://creativecommons.org/licenses/by/4.0/), which permits unrestricted use distribution, and reproduction in any medium, provided you give appropriate credit to the original author (s) and the source, provide a link to the Creative Commons license, and indicate if changes were made.

\section{Appendix}

Twelve of beta's variant readings and six of theta's (in red) match those of the Hathapradīpikā.

\begin{tabular}{|c|c|c|c|c|}
\hline Verse No. & Theta & Beta & Haṭhapradīipikā Ed. & Hațhapradīipikā Mss. \\
\hline $9 a$ & citte samatvam & citte tu sattvam & citte samatvam & \\
\hline $29 \mathrm{c}$ & prasāritam padam & pādaṃ prasāritam & prasāritam padaṃ & $\begin{array}{l}\text { pādaṃ prasāritaṃ Kha, } \mathrm{Pa} \\
\text { pādaprasāritaṃ Ka, Ga, Pha }\end{array}$ \\
\hline $29 c$ & kṛtvā & dhṛtvā & kṛtvā & dhṛtvā Kha, Pa, Ga, Pha \\
\hline $32 a$ & $\begin{array}{l}\text { mahārogā } \\
\text { mahākleśā }\end{array}$ & mahākleśādayo doșā & mahākleśādayo doșāḥ & \\
\hline $32 b$ & jïryante & bhidyant & kșiyante & jïryante Ga, Ta \\
\hline $34 \mathrm{~b}$ & hṛdaye cibuke krrte & $\begin{array}{l}\text { cibukam hṛdaye } \\
\text { dṛ̣ham }\end{array}$ & $\begin{array}{l}\text { hṛdaye cibuke } \\
\text { dṛdham }\end{array}$ & \\
\hline $35 b$ & gativiśodhanah & gativibodhakah & gatinirodhakah & $\begin{array}{l}\text { gamanabodhakah Ka, Kha, Ga } \\
\text { gativibodhakah Pha }\end{array}$ \\
\hline $35 c$ & gatvā & dhatte & dhatte & \\
\hline $38 \mathrm{c}$ & āvṛtya & ārudhya & āvrrtya & \\
\hline $39 a$ & bhūtvā & bhūmau & bhūmau & \\
\hline $40 \mathrm{c}$ & samākramya & samākrșya (Ga) & atikramya & $\begin{array}{l}\text { samākṛșya Ka, Kha, Ta, Tha, Pa } \\
\text { samākramya Ga }\end{array}$ \\
\hline $42 \mathrm{c}$ & caitad & caiva & caiva & \\
\hline $45 \mathrm{~d}$ & $\begin{array}{l}\text { yogāvasthā } \\
\text { caturvidhā }\end{array}$ & $\begin{array}{l}\text { cetasas tasya } \\
\text { bhūmikāh }\end{array}$ & $\begin{array}{l}\text { syād avasthā } \\
\text { catusțayam }\end{array}$ & \\
\hline $46 a$ & vedhād & bhedād & bhedād & \\
\hline $47 b$ & -gandhas tv & -gandho hy & -gandhas tv & \\
\hline $47 \mathrm{c}$ & -hṛdayah śūra & -hṛdaye śūnye tv & -hṛdayah śūnya & \\
\hline $48 \mathrm{a}$ & $\begin{array}{l}\text { dvitīyāyām } \\
\text { ghațikkrtya }\end{array}$ & dvitīye saṃhațikrrtya & dvitīyāyāṃ ghațîkrtya & \\
\hline $48 \mathrm{~d}$ & $\begin{array}{l}\text { jñānād eva } \\
\text { samaprabhah }\end{array}$ & jñānī devasamas tadā & jñānī devasamas tathā & $\begin{array}{l}\text { jñānī devasamas tadā Ka, Gha, } \\
\text { Ya, Va }\end{array}$ \\
\hline $49 a$ & tathā & tato & tato & \\
\hline $49 \mathrm{a}$ & vedhāt & bhedāt & bhedāt & \\
\hline $50 \mathrm{c}$ & tadā & tato & tadā & \\
\hline $50 \mathrm{~d}$ & sarvasandhi- & sarvasiddhi- & sarvasiddhi- & \\
\hline $51 \mathrm{a}$ & tato jitvā & rocitvāt & tadā jitvā & \\
\hline $51 \mathrm{c}$ & doșamrrtyu- & doșaduhikha- & doșaduḥkha- & \\
\hline $51 \mathrm{~d}$ & -duhkha- & -mrityu- & -vyādhi- & -mrrtyu- Ga \\
\hline
\end{tabular}




\section{References}

\section{Primary Sources}

Amanaska

The Amanaska: king of all Yogas. A critical edition and annotated translation with a monographic introduction. Jason Birch. DPhil dissertation, University of Oxford Library, Oxford, 2013.

Amaraughaprabodha

$\mathrm{G}_{1}$ - Amaraughaprabodha. Ms. No. 1448. Government Oriental Manuscript Library, Madras (Chennai).

$\mathrm{G}_{2}-$ Amaraughaprabodha. Ms. No. 4340. Government Oriental Manuscript Library, Madras (Chennai).

B - Amaraughaprabodha. Ms. No. 7970. Maharaja Sayajirao Oriental Institute, Central Library, Baroda (Vadodara).

$\mathrm{A}_{1}$ - Amaraughaprabodha. Ms. No. 70528. Adyar Library and Research Centre, Chennai.

$\mathrm{A}_{2}$ - Amaraughaprabodha. Ms. No. 75278. Adyar Library and Research Centre, Chennai.

T - Amaraughaprabodha. Ms. No. 179(a) [Serial number 412]. Venkateśvara Oriental Institute, Tirupati. Amṛtasiddhi

Amrtasiddhi, (unpublished) critical edition, ed. James Mallinson and Péter-Dániel Szántó. The Hatha Yoga Project, forthcoming.

Dattātreyayogaśāstra

Dattātreyayogaśāstra. (unpublished) critical edition, ed. James Mallinson (compiled with assistance from Alexis Sanderson, Jason Birch, Péter Szántó, and Andrea Acri). The Hatha Yoga Project, forthcoming.

Gorakșaśataka

Goraksaśataka. Ms. No. R 7874 (IFP transcript T1095). A transcript of Ms. No. 2831(p). Government Oriental Manuscript Library, Madras (Chennai).

Gorakșaśataka. Ms. No. B6389 (Call No. 6717) Thanjavur Maharaja Serfoji’s Sarasvati Mahal Library and Research Centre, Thanjavur.

Gherandasamhitā

The Gheraṇda Saṃhitā: The original Sanskrit and an English translation. Mallinson, J. Woodstock: YogaVidya.com, 2004.

Gorakh Bānīi

Gorakha-bānī, ed. Doktar Pītāmbaradatta Baḍathvāla. Prayāga: Hindī Sāhitya-sammelana. 2nd edition 2003 (vi) $[=1946 \mathrm{CE}]$

Hațhapradīpikā

Haṭapradīpikā, manuscript no. 30109. Sampūrn̄ānanda Library, Varanasi.

Hațapradīpikā of Svātmārāma, ed. Swami Digambaraji and Pt. Raghunatha Shastri Kokaje. Lonavla: Kaivalyadhama S. M. Y. M. Samiti, 1998.

Hațapradīpikā of Svātmārāma with the Commentary Jyotsnā Brahmānanda, ed. K. Kunjunni Raja. Madras: Adyar Library and Research Centre, 1972 (Verse numbers are cited from this edition).

Hațhapradīpikā (with 10 chapters) of Svātmārāma: with Yogaprakāsíkā, a commentary by Bālakṛsna, ed. Gharote, M.L. and Devnath, P. Lonavla: Lonavla Yoga Institute, 2006.

Hațhasanketacandrikā (of Sundaradeva)

Hathasanketacandrikā, ms. No. 2244 at the Man Singh Pustak Prakash Library, Jodhpur.

Jyotsnā (of Brahmānanda)

Brahmānandakrtā Hathapradīpikā Jyotsnā, ed. Maheśānand, Śarmā, Sahāy and Bodhe. Lonavla: Kaivalyadham Śrīmanmādhav Yogamandir Samiti, 2002.

Kubjikāmatatantra

The Kubjikāmatatantra: Kulālikāmnāya version, ed. Goudriaan, T. and Schoterman, J.A. Leiden: E.J. Brill, 1988.

Kuñcitānghristava

See Smith 1996

Pātañjalayogaśāstra

Pātañjalayogasūtrāni vācaspatimiśraviracitațīkāsamvvalitavyāsabhāsyasametāni tathā bhojadevaviracitarājamārtanḍābhidhavrttisametāni, Ānandāśramasaṃ skṛtagranthāvaliḥ, 47. ed. Kāśīnātha Śāstrī Āgāsé, Hari Nārāyana Āpatẹ, Pune: Ānandāśramamudranāāaya, 1904. 


\section{Netratantra}

Netratantra with the commentary (Netroddyota) of Rājānaka Kṣemarāja, ed. Madhusūdan Kaul Sāstrī. KSTS 46, 59. Bombay, 1926 and 1939.

Niśvāsaguhya

The Niśvāsatattvasaṃhitā: The earliest surviving Śaiva tantra. Dominic Goodall. Pondicherry: Institut Français de Pondichéry.

Sārdhatriśatikālottara

Sārdhatriśatikālottaravrtti of Bhațta Rāmakaṇtha, ed. N.R. Bhatt: Sārdhatriśatikālottarāgama avec le commentaire de Bhațta Rāmakaṇțha: édition critique. Publications de l'IFI, No. 61. Pondicherry: IFI, 1979.

Śārngadharapaddhati

Śārnigadharapaddhati, ed. Peter Peterson. Delhi: Caukhambā Saṃskṛta Pratișțhāna, 1987.

Saubhāgyalakṣmyupaniṣat

See Yoga Upanișads

Śivasaṃitā

The Śiva Saṃitā: A critical edition and an english translation. Mallinson, J. Woodstock: YogaVidya. com, 2007.

Svacchandatantra

Svacchandatantra with the commentary (Svacchandoddyota) of Rājānaka Kșemarāja, ed. Madhusūdan Kaul Śāstrī. KSTS 31, 38, 44, 48, 51, 53, 56. Bombay, 1921-1935.

Tantrasadbhāva

Tantrasadbhāva (Partially and Provisionally edited etext by Mark Dyczkowski). Etext of the Digital Library of Muktabodha (http://muktabodha.org).

Upāsanāsārasañgraha

Upāsanāsārasañgraha, Institut Français de Pondichéry Transcript No. T1095b [R 2831(i)], pp. 15-63.

Varāhopanișat

See Yoga Upaniṣads

Vasișthasamhitā

Vasiṣtha Saṃhitā (Yoga Kāṇ̣̂), revised edition, ed. Philosophico-Literary Research Department. Lonavla: Kaivalyadhama S.M.Y.M. Samiti, 2005.

Vivekamārtaṇda

Vivekamārtạ̣ḍ. Ms. No. 4110. Maharaja Sayajirao Oriental Institute, Central Library, Baroda (Vadodara).

Yogabīja

Yogabīja of Gorakhanātha, ed. Ramalala Srivastava. Gorakhapur: Gorakhanath Mandir, 1982.

Yogacintāmani (of Śivānandasarasvatī)

Yogacintāmaṇi, ed. Haridāsa Śarma. Calcutta: Calcutta Oriental Press (no date).

Yogaprakāśikā

See Hațapradīpikā (with 10 chapters) 2006

Yogasārasangraha

Yogasārasañgraha. Institut Français de Pondichéry Transcript No. T0859.

Yogasiddhāntacandrikā

Pātañjalayogasūtravyākhyā paramahamsaparivrājakācāryaśrīnārāyaṇatīrthaviracitā yogasiddhāntacandrikā, ed. Dr. Vimalā Karnāțak. Chowkhambā Sanskrit Series Office (No 108).Varanasi: Benares Hindu University, 2000.

Yogatārāvalī

Yogatārāvalī, (unpublished) critical edition, ed. Jason Birch. The Hatha Yoga Project, forthcoming. Yoga Upanișads 
Yoga Upaniṣads with the Commentary of Śrī Upanișadbrahmayogin, ed. Pandit A. Mahadeva Sastri.

Madras: Adyar Library and Research Centre, 1968.

Yogavārttika (of Vijñānabhikṣu)

Yogavārttika of Vijñānabhikșu, ed. and trans. Rukmani, T.S., vol. 1-4. New Delhi: Munshiram Manoharlal

Publishers, 2007.

Yogayājñavalkya

Yogayājñavalkya, ed. Sri Prahlad C Divanji. B. B. R. A. Society’s Monograph, no. 3. Bombay: Bombay Branch Royal Asiatic Society, 1954.

Yuktabhavadeva

Yuktabhavadeva of Bhavadeva Miśra, ed. Gharote, M. L. and Jha, V. K. Lonavla: Lonavla Yoga Institute, 2002.

\section{Secondary Sources}

Banerjea, A. K. (1962). Philosophy of Gorakhnath: with Goraksha-vacana-sangraha. Gorakhpur: Mahant Dig Vijai Nath Trust.

Birch, J. (2011). The meaning of Hațha in early Haṭhayoga. JOAS, 131(4), 527-554.

Birch, J. (2014). Rājayoga: The reincarnations of the king of all Yogas. International Journal of Hindu Studies, 17(3), 401-444.

Birch, J. (2018). The proliferation of Āsanas in Late Medieval Yoga Texts. In Yoga in transformation: Historical and contemporary perspectives on a global phenomenon (pp. 101-179). Göttingen: Vandenhoeck \& Ruprecht Unipress.

Birch, J. (2019 Forthcoming). The quest for liberation-in-life in early Hața and Rājayoga" in Religious Practice. Oxford: The [Oxford] History of Hinduism, Oxford University Press.

Bouy, C. (1994). Les Nātha-Yogin et Les Upaniṣads. Paris: Diffusion De Boccard.

Briggs, W. (1938). Gorakhnāth and the Kānpața Yogis. Calcutta: Y.M.C.A. Publishing House.

Dasgupta, S. (1946). Obscure religious cults as background of Bengali literature. Calcutta: University of Calcutta.

Dvivedī, H. (1950). Nāth Sampradāy. Ilāhābād: Hindustān̄̄ Ekedemī.

Gonda, J. (1977). Medieval religious literature in Sanskrit (Vol. 2). Wiesbaden: Harrassowitz.

Goodall, D. (2004). The Parākhyatantra; a scripture of the Śaiva Siddhānta. Pondicherry: Institut Français de Pondichéry: École Française D’ Extreme-Orient.

Hatley, S. (forthcoming). Kuṇụlinī. In: Sharma, A. (ed) Encyclopedia of Indian religions. New York: Springer

Hellwig, O. (2009). Wörterbuch der mittelalterlichen indischen Alchemie. Eelde, the Netherlands: Barkhuis.

Kaivalyadhama Yoga Institute. (2005). Descriptive catalogue of yoga manuscripts (revised ed.). Lonavla, India: Kaivalyadhama S.M.Y.M. Samiti.

Mallik, K. (1954). Siddha-Siddhānta-Paddhati and other works of the Nātha Yogīs. Pune: Poona Oriental Book House.

Mallinson, J. (2007). The Khecarīvidyā of Ādinātha: A critical edition and annotated translation of an early text of Hathayoga. London: Routledge.

Mallinson, J. (2011). Hatha Yoga. In The Brill encyclopedia of Hinduism (Vol. 3, pp. 770-781). Leiden: Brill.

Mallinson, J. (2014). Hathayoga's philosophy: A fortuitous union of non-dualities. Journal of Indian Philosophy, 42(1), 225-247. https://doi.org/10.1007/s10781-013-9217-0.

Mallinson, J. (2016). Śāktism and Hațhayoga. In Olesen, B. W. (Ed.) Goddess traditions in tantric Hinduism, history, practice and doctrine (pp. 109-140). Oxford: Routledge.

Mallinson, J. (2016b). The Amṛtasiddhi: Hațhayoga's tantric Buddhist source text (draft July 3, 2016) Alexis Sanderson's Festschrift, forthcoming. https://www.academia.edu/26700528/The_Amrtasiddhi_ Hațhayogas_Tantric_Buddhist_Source_Text. Accessed 20 November 2018.

New Catalogus Catalogorum (NCC). (1949). New catalogus catalogorum: An alphabetical register of Sanskrit and allied works and authors, vol. 1. Raghavan, V., Kunjunni, R. K., Veezhinathan, N., Ramabai, E. R., Dash, S., \& Aufrecht, T. Madras: University of Madras.

Rañgācarya, A., \& Bahudur, R. (1910). A descriptive catalogue of Sanskrit manuscripts in the Government Oriental Manuscripts Library, Madras (Vol. 9). Madras: Superintendent Government Press. 
Sanderson, A. (2001). 'History through textual criticism in the study of Śaivism, the Pañcarātra and the Buddhist Yoginītantras. In F. Grimal (Ed.), Les Sources et le temps. Sources and time: A colloquium, Pondicherry, 11-13 January 1997 (pp. 1-47). Pondicherry: Institut Français de Pondichéry École Française d'Extrême-Orient.

Sanderson, A. (2003). Śaiva religion among the Khmers, Part 1. Bulletin de l'École française d'ExtrêmeOrient, 90-91, 349-462.

Schaeffer, K. R. (2002). Thee attainment of immortality: From Nāthas in India to Buddhists in Tibet. Journal of Indian Philosophy, 30, 6.

Sferra, F. (2000). The Sadangayoga by Anupamaraksita: With Ravisrijñanas Gunabharaninamasadangayogatippani: Text and annotated translation. Roma: Istituto italiano per l'Africa e l'Oriente.

Smith, D. (1996). The dance of Śiva: Religion, art and poetry in South Asia. Cambridge: Cambridge University Press.

Sri Venkatesvara University and Sastri, S. N. (1956). An alphabetical index of Sanskrit, Telugu \& Tamil manuscripts, palm-leaf and paper, in the Sri Venkateswara Oriental Research Institute Library, Tirupati $=$ [Śrīveñkațeśvaraprācya-pariśodhanālayabhāṇd̄āgārīyalikhitagranthasūcū $]$. Ed. N. Subramania Sastri. Tirupati: Sri Venkateswara Oriental Research Institute.

Szántó, P.-D. (2016). A brief introduction to the Amrtasiddhi (Handout for a talk presented at the Hatha Yoga Project's Workshop, SOAS University of London). https://www.academia.edu/28522189/ _A_Brief_Introduction_to_the_Amrtasiddhi_Handout_for_Sanskrit_Texts_on_Yoga_London_Oxford_ 2016_. Accessed 9 February 2017.

Tāntrikābhidhanākośa. (2000). Tāntrikābhidhānakośa. I dictionnaire des termes techniques de la littérature hindoue tantrique $=$ Wörterbuch zur Terminologie hinduistischer Tantren. Ed. Dominic Goodall; Hélène Brunner-Lachaux; et al.

Wien: Verlag der Österreichischen Akademie der Wissenschaften. (2013). Tāntrikābhidhanākośa III: Dictionnaire des termes techniques de la. eds Goodall, Dominic and Rastelli, Marion. Austria: Austrian Academy of Science.

Vasudeva, S. (2004). The Yoga of the Mālinīvijayottaratantra: Chapters 1-4, 7-11, 11-17, critical edition, translation and notes. Pondicherry: École française d'Extrême-Orient.

White, D. G. (1996). The alchemical body. Chicago: University of Chicago Press.

Publisher's Note Springer Nature remains neutral with regard to jurisdictional claims in published maps and institutional affiliations. 